\title{
Chitin- and cellulose-based sustainable barrier materials: a review
}

\author{
Zeyang $\mathrm{Yu}^{1} \cdot$ Yue $\mathrm{Ji}^{1} \cdot$ Violette Bourg ${ }^{2} \cdot$ Mustafa Bilgen $^{3} \cdot$ J. Carson Meredith ${ }^{1,4}$ (I)
}

Received: 13 September 2020 / Accepted: 23 November 2020 / Published online: 9 December 2020

(C) The Author(s) 2020

\begin{abstract}
The accumulation of synthetic plastics used in packaging applications in landfills and the environment is a serious problem. This challenge is driving research efforts to develop biodegradable, compostable, or recyclable barrier materials derived from renewable sources. Cellulose, chitin/chitosan, and their combinations are versatile biobased packaging materials because of their diverse biological properties (biocompatibility, biodegradability, antimicrobial properties, antioxidant activity, non-toxicity, and less immunogenic compared to protein), superior physical properties (high surface area, good barrier properties, and mechanical properties), and they can be assembled into different forms and shapes (powders, fibers, films, beads, sponges, gels, and solutions). They can be either assembled into packaging films or used as fillers to improve the properties of other biobased polymers. Methods such as preparation of composites, multilayer coating, and alignment control are used to further improve their barrier, mechanical properties, and ameliorate their moisture sensitivity. With the growing application of cellulose and chitin-based packaging materials, their biodegradability and recyclability are also discussed in this review paper. The future trends of these biobased materials in packaging applications and the possibility of gradually replacing petroleum-based plastics are analyzed in the "Conclusions" section.
\end{abstract}

Keywords Chitin $\cdot$ Cellulose $\cdot$ Biobased packaging materials $\cdot$ Gas barrier properties

\section{Introduction}

One of the greatest challenges in keeping plastics out of landfills and the environment is flexible and rigid gas barrier materials used in food, medical, and pharmaceutical packaging. Formed from petroleum-derived polymer multilayers, sometimes layered with aluminum, and often contaminated with food, these materials are unrecyclable by current means. As a result, they contribute approximately 750 million pieces of packaging plastic, 22 million tons, to landfills or environmental leakage annually $[1,2]$. Opportunity exists to reduce endof-life plastics and create packaging that fulfills tenets of circular products through the utilization of biomass-derived

J. Carson Meredith

carson.meredith@chbe.gatech.edu

1 Department of Chemical and Biomolecular Engineering, Georgia Institute of Technology, 311 Ferst Dr NW, Atlanta, GA 30332, USA

2 Nestlé Research Science, Route du Jorat, 57, 1000 Lausanne, Switzerland

3 Department of Innovation, Technology \& Commercialization, Winpak, 100 Wihuri Parkway, Senoia, GA 30276, USA

4 The Renewable Bioproducts Institute, Georgia Institute of Technology, 500 10th St. NW, Atlanta, GA 30332, USA materials, because these materials are often renewably sourced and degradable via naturally existing pathways. Currently, there exists no fully biodegradable biomass-derived barrier packaging alternative that meets barrier, mechanical, and sealing performance criteria and is cost-competitive with incumbent barriers.

Shelf-stable food, beverage, and healthcare packaging require certain oxygen and moisture transport properties, dependent on the packaged material and the intended shelf life. For example, very dry products (e.g., instant coffee) require oxygen transport rate (OTR) as low as $0.2 \mathrm{~cm}^{3} \mathrm{~d}^{-1} \mathrm{~m}^{-2}$ and water vapor transport rate (WVTR) of $0.7 \mathrm{~g} \mathrm{~m}^{-2} \mathrm{~d}^{-1}$ (normalized to $100 \mu \mathrm{m}$ thickness) [3-5]. Other products are packaged at higher OTR and WVTR values, such as meat that ranges from OTR of 2 to $40 \mathrm{~cm}^{3} \mathrm{~d}^{-1} \mathrm{~m}^{-2}$ and WVTR of 2 to $50 \mathrm{~g} \mathrm{~m}^{-2} \mathrm{~d}^{-1}$ [3-5]. Due to this range of barrier properties, as well as mechanical, printing, and sealing requirements, multiple materials are combined in a multi-layer configuration. Multilayer films are achieved via lamination or coextrusion processes. Some examples include poly(ethylene terephthalate) (PET) and polyolefin laminations, via an adhesive lamination process; coextruded layers of polyamide, poly(ethylene-co-vinyl alcohol) (EVOH), and polyethylene; and coextruded layers of PET, EVOH, and polyolefins. Most flexible multilayer packaging materials are collected with household waste and 
landfilled. In 2013, of the estimated 30 million tons of flexible packaging, $40 \%$ was landfilled and another $32 \%$ was "leaked" to the environment [2]. About $14 \%$ of the plastic was collected for recycling and the remainder was incinerated for energy. Only $5 \%$ of the packaging original value was retained, resulting in losses as high as $\$ 120$ billion per year [2].

In considering biomass sources of potential barrier polymers, naturally occurring poly(saccharides) are of interest due to their abundance, high crystallinity at the nanofiber or nanocrystal level, and inherent microbial biodegradability. For example, cellulose and chitin are the first and second most abundant naturally derived carbohydrate polymers, produced in nature at $10^{10}$ to $10^{12}$ tons annually $[6,7]$. Cellulose and chitin are found in hierarchical structures in plant cell walls and crustacean exoskeletons, respectively, from which nanocrystals or nanofibers can be extracted. A significant infrastructure exists for converting plant and wood biomass into cellulose for paper products (in tens of millions of tons per year), and the extraction of chitin and chitosan from waste crustacean exoskeletons is an established and growing industry. For example, in 2015, 28 kt of chitosan were produced, valued at $\$ 3.2$ billion, a figure that in 2019 grew to $\$ 6.8$ billion and over $50 \mathrm{kt}$ with a projected annual growth of $24.5 \%$ between 2020 and 2027 [8]. Cellulose and chitin are each biodegradable by enzymes present in many organisms: fungi, bacteria, archaea, rotifers, and algae $[9,10]$. Chitin interacts with both the carbon and nitrogen cycles, an advantage compared to other compostable polymers. Chitin and cellulose mixed streams have been shown to be industrially compostable, although these were not concentrated nanocrystalline or nanofibrillar forms [11]. In addition to degradation, these materials also present opportunities for recycling. Indeed, paper is recycled more than any other commodity in the solid waste stream. Figure 1 is a schematic representing the concepts presented in this review from the perspective of the product lifecycle. Each of these concepts and examples from the literature will be described in detail from material selection and properties, structural design, manufacturing methods, to end-of-life biodegradation or composting.

Because of their high crystallinity cellulose nanocrystals (CNCs), cellulose nanofibrils (CNFs) [12], chitin nanocrystals (ChNCs), and chitin nanofibrils (ChNFs) [13] are excellent candidates for $\mathrm{O}_{2}$ barrier films $[14,15]$. However, the development of barrier properties depends dramatically on processing. While considerable literature has explored the barrier properties of $\mathrm{CNC}, \mathrm{CNF}$, ChNF, and ChNC films, unfortunately, much of the literature focuses on neat solution-cast films, dried on a timescale too slow for practical manufacturing. The opposite charges of chitin (cationic) and cellulosic (anionic) nanomaterials are believed to provide opportunities to promote faster deposition by synergistic attractions that can aid the formation of dense barrier materials [16]. Thus blending and layering may lead to more efficient formation of dense high-barrier structures. Indeed, blending chitin and cellulose nanomaterials is an idea dating back to 1992 [17], but layering them to take advantage of synergistic charge interactions is a recently emerging technology. We point to other reviews that have focused more broadly on polysaccharides [18] and other biobased polymers for packaging [19], but we focus the present review on this emerging technology of combining cellulosic and chitinous nanomaterials to create films with oxygen barrier properties. First, we discuss the extraction of the nanomaterials from biomass feedstocks, and then review the barrier properties that have been reported for neat, blended, and layered chitin and cellulose materials. The biodegradation and recycling potential is discussed as well. We omit discussions of fillers that may be viewed as nonrenewable or that impact end-of-life handling negatively, such as graphene and other carbon-based nanoparticles. The review concludes by proposing several challenges that remain to advance these materials as practical solutions in packaging applications.

\section{Chitin and cellulose}

\subsection{Sources and extraction process}

Cellulose is a homopolymer of D-glucose (Fig. 2) linked through $\beta-1,4$ glycoside bonds. It is the most abundant biopolymer in nature. Its worldwide production is estimated to be $10^{10}-10^{11}$ t per year [20]. Cellulose has been used in daily life for thousands of years in the form of wood, paper, and textiles due to its flexibility and strength. Wood is the most abundant source of cellulose in nature, which has a multilayered hierarchical structure (Fig. 3a). Bundles of cellulose microfibrils (CMFs) are embedded in the matrix of hemicellulose and lignin to form a wood cell wall. Each microfibril is a strand of CNCs linked by amorphous regions. Typical CMFs have a diameter of 5-60 $\mathrm{nm}$ and a length of several micrometers [21]. Individual CNCs have a diameter of 3-5 nm and a length of $50-500 \mathrm{~nm}$ [12]. To extract cellulose nano- or micromaterials, the non-cellulose matrix is removed, and the fibers are separated. The purification process is dependent on the source of cellulose due to various types of impurities, such as lignin and hemicellulose that are often removed by alkali. Depending on the desired size of the product, different separation methods are applied. For example, mechanical processing, including high-pressure homogenization, sonication, and grinding, is usually applied to disintegrate the cellulose fibers and generate CMFs or CNFs [22]. Acid hydrolysis is applied to remove the amorphous regions of cellulose and produce CNCs, and sulfuric acid is the most widely utilized. Notably, acid hydrolysis introduces anionic sulfate groups to the CNC surface by esterification of the hydroxyl groups.

Chitin is the second most abundant biopolymer in nature. Similar to cellulose, chitin is a homopolymer of N-acetyl 


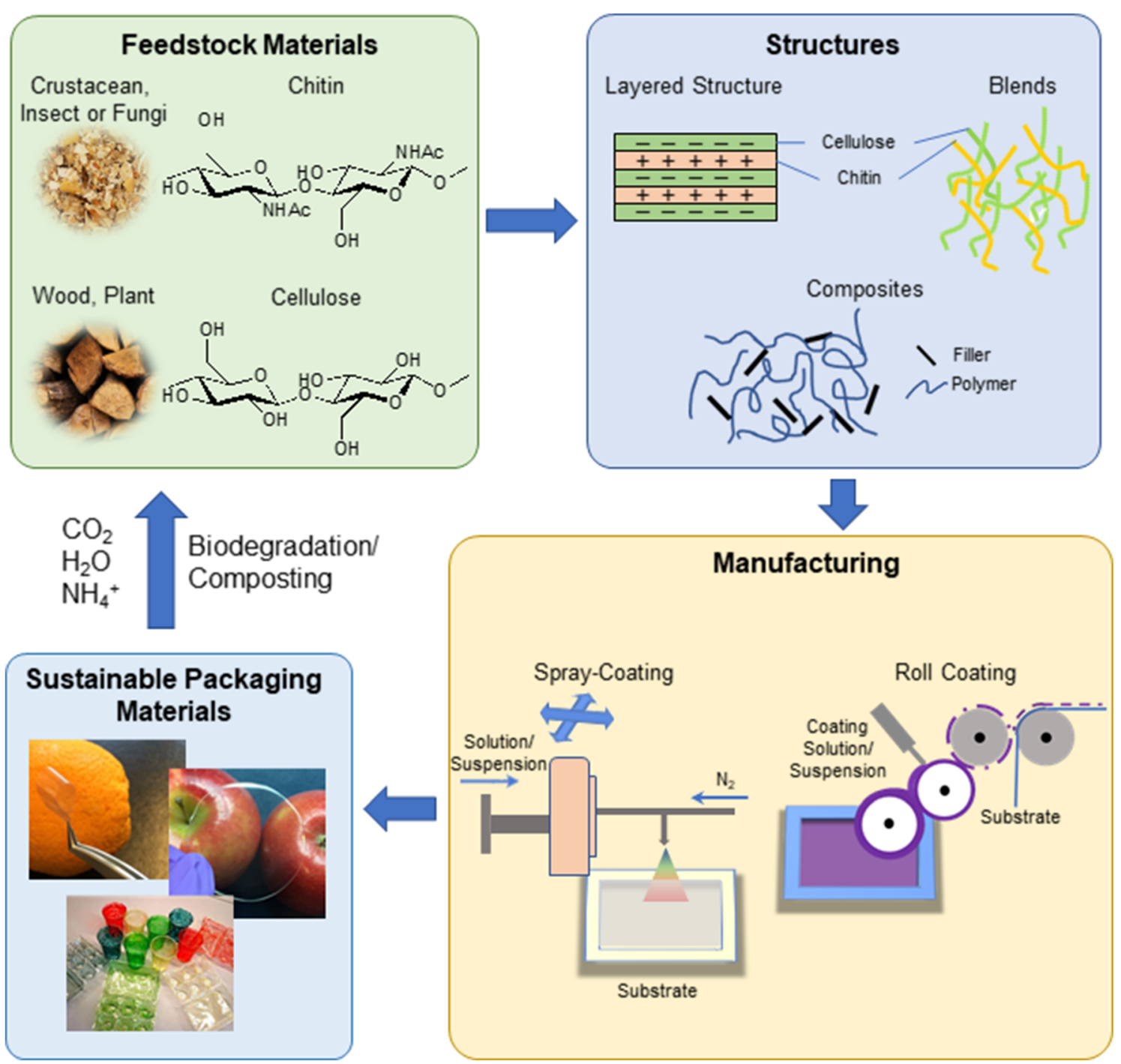

Fig. 1 Life-cycle for chitin and cellulose-based sustainable packaging materials

glucosamine (Fig. 2). Chitin occurs mainly in the exoskeletons of shellfish and insects and the cell walls of mushrooms, with a biosynthesis rate of $10^{10}-10^{11}$ t per year [13]. Shellfish exoskeletons are the most common source for producing commercial chitin in the form of chitosan. Shellfish exoskeletons have a hierarchical structure (Fig. 3b) in which networks of ChNF bundles are embedded in the matrix of protein and calcite. Several chitin chains are bundled to form ChNFs with

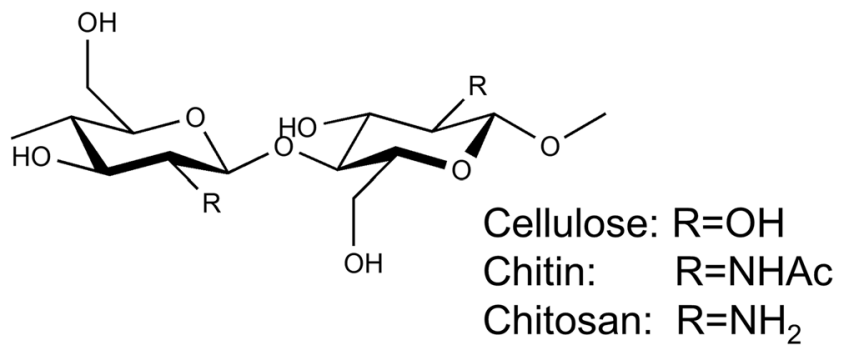

Fig. 2 Chemical structures of cellulose, chitin, and chitosan. Ac = acetate
2-5 $\mathrm{nm}$ in diameter and around $300 \mathrm{~nm}$ in length, which consist of crystalline (ChNCs) and amorphous regions. Commonly, extraction of chitin from exoskeleton involves deproteination in alkaline solution, demineralization in acidic solution, and discoloration in organic solution, although other approaches such as ionic liquids are under development [23]. An additional step of deacetylation in alkaline solution is sometimes applied to partially hydrolyze the acetamide groups and produce chitin with a lower degree of acetylation (DA), such as chitosan (Fig. 2) whose DA is $0-50 \%$. Chitin is cationic in acidic solution when amine groups become protonated. The methods of producing ChNFs and ChNCs are similar to those for cellulose, which typically involve mechanical processing for producing ChNFs and acid hydrolysis for producing ChNCs or chitin nanowhiskers (ChNWs). Other methods can also be applied to produce ChNCs and ChNFs, such as TEMPO oxidation and alkaline treatment [24]. 
(a)
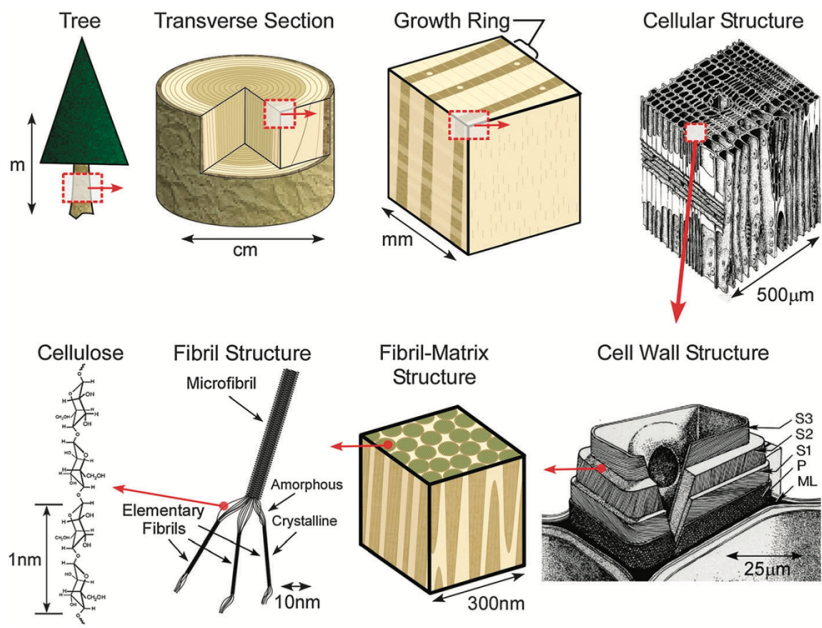

(b)

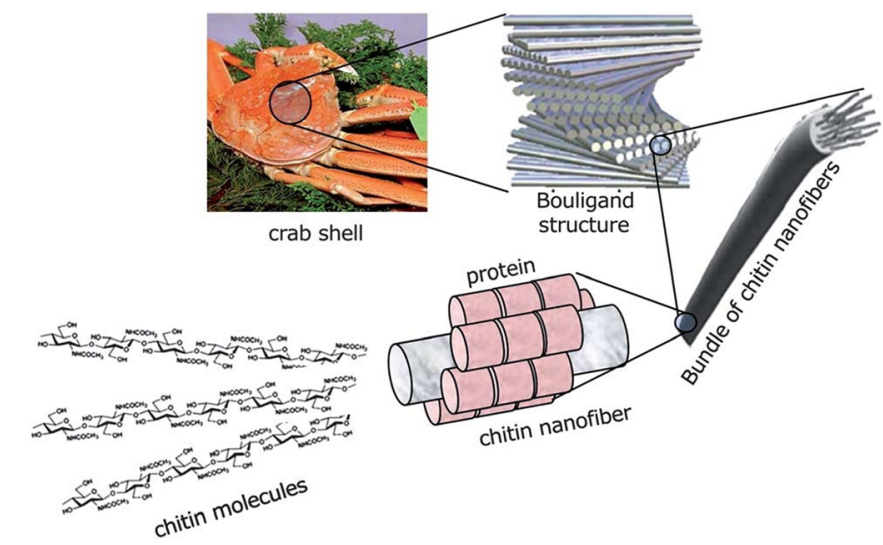

Fig. 3 Hierarchical structures of (a) wood as a major industrial source of cellulose [12] and (b) crab shell as an example chitin source [13]. (Reproduced with permission)

\subsection{Property overview of neat cellulose and chitin}

Before going into a detailed view of the barrier properties of the many different forms of cellulose and chitin (films, coatings, filled, blended, layers, etc.), we offer a brief overview of neat material properties. Because cellulose and chitin nano- or micromaterials have high crystallinity and strong inter- and intra-sheet hydrogen bonding, they have attractive mechanical and barrier properties. The crystalline region of cellulose has an elastic modulus of $134 \mathrm{GPa}$ [25] and a tensile strength of 7.6 GPa [12]. The elastic modulus and tensile stress of individual ChNFs are estimated to be $>150 \mathrm{GPa}$ [26] and 1.6 GPa, respectively [27]. It has been shown that films of neat CNCs [28-30], CNFs [31, 32], ChNFs [15, 30], ChNWs [24, 33], and ChNCs [34, 35] have low oxygen permeability (OP). Xia et al. [32] fabricated highly transparent 2,2,6,6-tetramethylpiperidine-1-oxyl (TEMPO)-oxidized CNF films with sodium borohydride reducing agent. Freestanding films had an OP of $0.203 \mathrm{~cm}^{3} \mu \mathrm{m} \mathrm{m}^{-2}$ day $^{-1} \mathrm{kPa}^{-1}$ and a water vapor transmission rate (WVTR) of $115 \mathrm{~g} \mathrm{~m}^{-2}$ day $^{-1}$ at $23{ }^{\circ} \mathrm{C}$ and $50 \%$ relative humidity (RH). Both WVTR and OP improved with thermal annealing. Film treated at $145{ }^{\circ} \mathrm{C}$ had an exceptionally low OP of $0.007 \mathrm{~cm}^{3} \mu \mathrm{m} \mathrm{m} \mathrm{m}^{-2} \mathrm{day}^{-1} \mathrm{kPa}^{-1}$ and a WVTR of $12.3 \mathrm{~g} \mathrm{~m}^{-2}$ day $^{-1}$, indicating the enhancements possible when interfibrillar water is removed and inter-fiber hydrogen bonds are formed. Martinez-Sanz et al. [36] prepared bacterial CNC films with an OP of $0.06 \mathrm{~cm}^{3} \mu \mathrm{m} \mathrm{m}^{-2}$ day ${ }^{-1} \mathrm{kPa}^{-1}$ at $23{ }^{\circ} \mathrm{C}$ and $0 \%$ RH. Wu et al. [15] prepared self-standing ChNF films with an $\mathrm{OP}$ of $3.9 \mathrm{~cm}^{3} \mu \mathrm{m} \mathrm{m}^{-2}$ day $^{-1} \mathrm{kPa}^{-1}$ at room temperature and $0 \% \mathrm{RH}$. The permeabilities for other gases $\left(\mathrm{H}_{2}\right.$, $\mathrm{CO}_{2}, \mathrm{~N}_{2}$, and $\mathrm{CH}_{4}$ ) were also reported to be in the range from 1.75 to $15.6 \mathrm{~cm}^{3} \mu \mathrm{m} \mathrm{m}^{-2} \mathrm{day}^{-1} \mathrm{kPa}^{-1}$ at the same conditions.
In the reports above, the OP values were in a range lower than or near many petroleum-based plastics used for packaging, such as $10-50 \mathrm{~cm}^{3} \mu \mathrm{m} \mathrm{m}^{-2} \mathrm{day}^{-1} \mathrm{kPa}^{-1}$ for PET, $0.5 \mathrm{~cm}^{3} \mu \mathrm{m} \mathrm{m}^{-2} \mathrm{day}^{-1} \mathrm{kPa}^{-1}$ for poly(vinylidene chloride) (PVDC), and $\sim 0.05 \mathrm{~cm}^{3} \mu \mathrm{m} \mathrm{m}^{-2}$ day $^{-1} \mathrm{kPa}^{-1}$ for EVOH [37]. It should be pointed out that nearly all of these films were produced via solvent casting and slow evaporation, and thus faster deposition methods are required for scale-up to commercial production.

One of the challenges of most barrier materials, including those composed of chitin and cellulose nanomaterials, is the sensitivity of the OP to water vapor. While many studies do not report data for OP as a function of $\mathrm{RH}$, those that do (as reported above) generally see a rise in OP as RH increases. Two approaches appear to mitigate this sensitivity, each of which appears to enhance inter-fiber (chitin-chitin or cellulose-cellulose) hydrogen bonding. One approach is thermal annealing above $100{ }^{\circ} \mathrm{C}$ to drive off water, and the other is the use of multivalent cations to "crosslink" fibers and mitigate swelling with water vapor. Thermal annealing led to OP as low as $0.6 \mathrm{~cm}^{3} \mu \mathrm{m} \mathrm{m}^{-2}$ day $^{-1} \mathrm{kPa}^{-1}$ at $23{ }^{\circ} \mathrm{C}$ and $80 \% \mathrm{RH}$ [32] in CNF films and use of $\mathrm{Al}^{3+}$ ion in CNC films led to $0.08 \mathrm{~cm}^{3} \mu \mathrm{m} \mathrm{m}^{-2}$ day $^{-1} \mathrm{kPa}^{-1}$ at $23{ }^{\circ} \mathrm{C}$ and $80 \%$ RH [38].

\section{Gas barrier properties: coatings, blends, and nanocomposites with chitin and cellulose}

High-performance, biodegradable films with good mechanical properties, optical transparency, thermal stability, and high gas barrier properties are highly demanded in the current packaging market [18]. Barrier properties are crucial to evaluating and predicting the shelf-life of packaged products, and 
specific requirements for packaging film are related to the product characteristics and intended application. Water vapor and oxygen are two main gas permeates investigated in packaging applications, and uncontrolled transport of these gases into or out of the package leads to changes in product quality and diminished shelf-life [39]. Barrier properties to permeance of carbon dioxide is another important factor in some applications, such as when products are stored in a modified high $\mathrm{CO}_{2}$ environment to increase shelf-life. Because of the positive effects on mechanical properties and low permeability to oxygen, chitin and cellulose nanoparticles have been applied as neat films or as fillers for biobased polymers to produce sustainable packaging, discussed in the previous section.

Chitin and cellulose form a film that is capable of meeting many of the above-mentioned requirements. However, their sensitivity to moisture and generally poor barrier properties for water vapor transfer are the main drawbacks. Biodegradable films based on cellulose derivatives are very effective barriers to oxygen and aromatic compounds. Among the cellulose derivatives, methylcellulose is one of the most extensively investigated. The WVP values were reported in the range of $0.525 \times 10^{-10}$ to $0.598 \times 10^{-10} \mathrm{~g} \mathrm{~s}^{-1} \mathrm{~m}^{-1} \mathrm{~Pa}^{-1}$ with the thickness varying from 0.01 to $0.024 \mathrm{~mm}$ [18]. For chitin-based films, the WVP value strongly depends on the degree of deacetylation of chitin, solvent $\mathrm{pH}$, and type of acid [40]. Films prepared with low deacetylation-degree chitin showed a lower value of WVP as there were fewer hydrophilic groups. In the $\mathrm{pH}$ range of 3 to 4 , the WVP value increased with $\mathrm{pH}$. For the effect of acid, the WVP values of the chitinbased film obtained with formic or lactic acid as the solvents were $3.04 \times 10^{-5}$ or $2.34 \times 10^{-5} \mathrm{~g} \mathrm{~m}^{-1} \mathrm{~h}^{-1} \mathrm{~Pa}^{-1}$, respectively. These results were remarkably higher than the ones obtained with acetic or propionic acid as the solvents $[18,41]$. As a comparison, the WVP values reported for several synthetic polymers were $0.7 \times 10^{-13}-2.4 \times 10^{-13} \mathrm{~g} \mathrm{~m}^{-1} \mathrm{~s}^{-1} \mathrm{~Pa}^{-1}$ for polyvinylidene chloride, $2.4 \times 10^{-13} \mathrm{~g} \mathrm{~m}^{-1} \mathrm{~s}^{-1} \mathrm{~Pa}^{-1}$ for highdensity polyethylene, $7.3 \times 10^{-13}-9.7 \times 10^{-13} \mathrm{~g} \mathrm{~m}^{-1} \mathrm{~s}^{-1} \mathrm{~Pa}^{-1}$ for low-density polyethylene, $4.9 \times 10^{-13} \mathrm{~g} \mathrm{~m}^{-1} \mathrm{~s}^{-1} \mathrm{~Pa}^{-1}$ for polypropylene, and $1.2 \times 10^{-12}-1.5 \times 10^{-12} \mathrm{~g} \mathrm{~m}^{-1} \mathrm{~s}^{-1} \mathrm{~Pa}^{-1}$ for polyester $[18,42]$. The main routes to improve the gas barrier properties can be divided as follows: (1) nanocomposite with other materials, (2) coating as single or multiple layers, (3) blending, and (4) alignment. The barrier properties for chitin and cellulose-based composite films, coatings, and blends are summarized in Table 1.

\subsection{Nanocomposites with cellulose and chitin}

Nanocomposites are constructed by dispersing a filler into a matrix (in our case a polymer matrix). The use of dense and impermeable nanoparticles forces the gas to diffuse through the polymer in a torturous path, decreasing the permeability and resulting in a higher barrier property (Fig. 4).
Fillers with a layered structure, like clay, graphene, and its derivatives, are commonly used to enhance gas barrier properties. Gas permeation can be described mathematically as a product of diffusivity and solubility, which are related to the flux of permeant normalized by the thickness and pressure driving force. A number of models have been developed to predict the gas permeability through the polymer matrix in the presence of high aspect ratio fillers [60-62]. In one model [62], permeability in the composite is related to filler volume fraction $(\phi)$ and aspect ratio $(L / W)$, shown in Eq. 1.

$\frac{P}{p}=\frac{1}{1+\left(\frac{L}{2 W}\right) \varnothing}$

where $P$ and $p$ are the permeability coefficients of the nanocomposites and the polymer matrix, respectively, the term $\tau=$ $1+(L / 2 W)$ is called the tortuosity factor. $L$ and $W$ are the length and thickness of the layered fillers. A higher filler aspect ratio offers a greater improvement in barrier properties (lower $P / p$ ). Generally speaking, uniform dispersion of nanoparticles throughout the matrix is required for the most significant permeability reduction its permeability [63].

\subsubsection{Nanoclay}

Lavorgna et al. [64] prepared chitosan and $\mathrm{Na}$ montmorillonite (Na-MMT) composites films, with glycerol as a plasticizer. Composite films with $10 \%(\mathrm{wt} / \mathrm{wt}) \mathrm{Na}-\mathrm{MMT}$ obtained a $30 \%$ and $50 \%$ reduction in water permeability, with or without glycerol, compared to neat chitosan. The tensile strength increased by $120 \%$ for the films containing glycerol. The improvements in the barrier and mechanical properties were attributed to the nanostructure of the films and the interactions between chitosan, Na-MMT, and glycerol. Park et al. [65] incorporated $1 \mathrm{wt} \%$ of clay into chitosan-coated on PLA film. With a $2 \mu \mathrm{m}$ chitosan-clay coating, the WVTR of PLA dropped by $14 \%$ and OTR decreased by $99.5 \%$. TEM results showed that a well-ordered and dispersed clay existed in the chitosan matrix. Wang et al. [66] prepared cellulose/MMT biobased plastics in which $20 \mathrm{wt} \%$ MMT gave the highest tensile strength and modulus (101 MPa and $3500 \mathrm{MPa}$, respectively, compared to $54 \mathrm{MPa}$ and $505 \mathrm{MPa}$ for neat cellulose). The permeability of $\mathrm{N}_{2}, \mathrm{H}_{2}, \mathrm{CH}_{4}$, and $\mathrm{CO}_{2}$ was investigated; the best results appeared at $20 \mathrm{wt} \%$ loading of MMT, which showed an improvement of $73 \%, 83 \%, 79 \%$, and $78 \%$ for each gas. With the addition of nanoclay, a decrease in the oxygen/moisture permeability is expected due to the reduced polymer matrix volume, as well as a drop in diffusion due to the formation of a more tortuous path for the gas molecules [67].

Enescu et al. [50] incorporated MMT and CNCs into chitosan (CS) films through solution mixing. The final film 
Table 1 Gas barrier properties: chitin/cellulose-based composites, coatings, and blends

\begin{tabular}{|c|c|c|c|c|c|}
\hline Materials & $\begin{array}{l}\text { Oxygen permeability } \\
\left(\mathrm{cm}^{3} \mu \mathrm{m} \mathrm{m}^{-2} \text { day }^{-1} \mathrm{kPa}^{-1}\right)\end{array}$ & Conditions & $\begin{array}{l}\text { Water vapor } \\
\text { permeability } \\
\left(\mathrm{g} \mathrm{\mu m} \mathrm{m}^{-2}\right. \\
\left.\text { day }^{-1} \mathrm{kPa}^{-1}\right)\end{array}$ & Conditions & Ref. \\
\hline \multicolumn{6}{|l|}{ Single-component film } \\
\hline $\mathrm{CNCs}$ & 18.5 & $23{ }^{\circ} \mathrm{C} 50 \%$ & - & - & {$[30]$} \\
\hline CMFs & $\begin{array}{l}0.2 \\
55\end{array}$ & $\begin{array}{l}23{ }^{\circ} \mathrm{C} 53 \% \\
23{ }^{\circ} \mathrm{C} 96 \%\end{array}$ & $\begin{array}{l}27,750 \\
27,750\end{array}$ & $\begin{array}{l}23{ }^{\circ} \mathrm{C} 100 / 50 \% \\
23{ }^{\circ} \mathrm{C} 100 / 50 \%\end{array}$ & {$[43]$} \\
\hline Carboxymethylated CNFs & $\begin{array}{l}0.4-0.8 \\
36\end{array}$ & $\begin{array}{l}23{ }^{\circ} \mathrm{C} 50 \% \\
23{ }^{\circ} \mathrm{C} 80 \%\end{array}$ & - & - & {$[44,45]$} \\
\hline Carboxylated CNFs & $0.6-1.5$ & $23{ }^{\circ} \mathrm{C} 50 \%$ & $2882-4220$ & $23{ }^{\circ} \mathrm{C} 50 / 0 \%$ & {$[46]$} \\
\hline ChNFs & 1.0 & $23{ }^{\circ} \mathrm{C} 50 \%$ & - & - & {$[30]$} \\
\hline Chitosan & $\begin{array}{l}1.1 \\
912.7\end{array}$ & $\begin{array}{l}25{ }^{\circ} \mathrm{C} 0 \% \\
25{ }^{\circ} \mathrm{C} 93 \%\end{array}$ & $\begin{array}{l}9198 \\
9198\end{array}$ & $\begin{array}{l}100 / 50 \% \\
100 / 50 \%\end{array}$ & {$[5]$} \\
\hline \multicolumn{6}{|l|}{ Composite films } \\
\hline TEMPO-CNFs/MTM (50 wt\%)/PET (substrate) & 0.0008 & $0 \%$ & - & - & {$[47]$} \\
\hline Trimethylammonium-NFCs/layered silicates (50 wt\%) & - & - & 2200 & $23{ }^{\circ} \mathrm{C} 85 / 0 \%$ & {$[48]$} \\
\hline Cellulose/attapulgite ( $20 \mathrm{wt} \%)$ & 0.320 & $23{ }^{\circ} \mathrm{C} 50 \%$ & - & - & [49] \\
\hline $\begin{array}{l}\text { MMT/chitosan/CNCs } \\
(3: 1: 6 \mathrm{w} / \mathrm{w} \%)\end{array}$ & 2.9 & $23{ }^{\circ} \mathrm{C} 50 \%$ & 19.3 & $23{ }^{\circ} \mathrm{C} 50 / 0 \%$ & {$[50]$} \\
\hline Chitosan/PVA/15 wt $\%$ MMT & 0.03 & $23{ }^{\circ} \mathrm{C} 0 \%$ & 4035 & $30^{\circ} \mathrm{C}$ & {$[51]$} \\
\hline $\begin{array}{l}\text { Chitosan/guar gum } \\
(25 \% \mathrm{v} / \mathrm{v})\end{array}$ & 0.4 & $23{ }^{\circ} \mathrm{C} 0 \%$ & 1406 & $37^{\circ} \mathrm{C} 10 / 15 \%$ & {$[52]$} \\
\hline Zein/chitosan/TiO2 (0.15 wt\%) & - & - & 2926 & $25{ }^{\circ} \mathrm{C} 53 / 0 \%$ & {$[53]$} \\
\hline \multicolumn{6}{|l|}{ Coating } \\
\hline CNFs/PLA & 2 & $23{ }^{\circ} \mathrm{C} 0 \%$ & 74 & $23{ }^{\circ} \mathrm{C} 90 / 10 \%$ & {$[5,54]$} \\
\hline $\mathrm{CNFs} / \mathrm{PET}$ & 4 & $23{ }^{\circ} \mathrm{C} 0 \%$ & 4.6 & $23{ }^{\circ} \mathrm{C} 90 / 10 \%$ & {$[5,54]$} \\
\hline $\mathrm{CNCs} / \mathrm{PET}$ & 20 & $23^{\circ} \mathrm{C} 0 \%$ & 4.7 & $38^{\circ} \mathrm{C} 100 / 0 \%$ & {$[29]$} \\
\hline $\mathrm{CNCs} / \mathrm{OPP}$ & 365 & $23^{\circ} \mathrm{C} 0 \%$ & 1.2 & $38^{\circ} \mathrm{C} 100 / 0 \%$ & {$[29]$} \\
\hline Chitosan/PE & $525-1157$ & $23{ }^{\circ} \mathrm{C} 50 \%$ & - & - & {$[55]$} \\
\hline TEMPO-ChNCs/PP & 203.8 & $23{ }^{\circ} \mathrm{C} 50 \%$ & - & - & {$[56]$} \\
\hline $\mathrm{ChNF/CNCs/PLA}$ & 27 & $23{ }^{\circ} \mathrm{C} 50 \%$ & 2.3 & $23{ }^{\circ} \mathrm{C} 50 / 5 \%$ & {$[16]$} \\
\hline $\mathrm{ChNW/CNFs/PET}$ & 0.01 & $23^{\circ} \mathrm{C} 0 \%$ & - & - & {$[57]$} \\
\hline Chitosan/CNCs/PET & 2.5 & $23{ }^{\circ} \mathrm{C} 0 \%$ & - & - & {$[58]$} \\
\hline \multicolumn{6}{|l|}{ Blends } \\
\hline Chitosan/CNCs (3:7 w/w\%) & - & - & 27.1 & $23{ }^{\circ} \mathrm{C} 50 / 0 \%$ & {$[50]$} \\
\hline ChNFs/CNCs $(1: 3 \mathrm{w} / \mathrm{w} \%)$ & 1.7 & $23{ }^{\circ} \mathrm{C} 50 \%$ & - & - & {$[30]$} \\
\hline Chitosan/CNCs (10 wt $\%)$ & - & - & 2230 & $25{ }^{\circ} \mathrm{C} 60 / 0 \%$ & {$[59]$} \\
\hline
\end{tabular}

contained 30\% (w/w) CS and 70\% (w/w) MMT/CNCs with $\mathrm{MMT}$ and $\mathrm{CNCs}$ combined with various weight ratios. Compared to the neat CS film, Young's modulus of $\mathrm{CNC}$ / CS binary composites increased by $148 \%$, but the tensile strength and failure strain were not significantly enhanced. Distinctive from the binary system, a synergistic effect was presented when adding both MMT and CNCs to the CS film. Adding CNCs into CS film led to a $62 \%$ increase in WVTR, but upon the incorporation of MMT into the CS matrix, the WVTR decreased by $54 \%$. The best result for the MMT/ $\mathrm{CNCs} / \mathrm{CS}$ system showed a $14 \%$ reduction in WVTR. The OTR, on the other hand, was significantly improved by the addition of both nanofillers. The OTR decreased by around
$80 \%$ for most composite samples, and the best results were obtained for the MMT/CNCs with a 1:4 weight ratio which showed an $85 \%$ OTR reduction. These results indicated that this ternary system created an efficient tortuous pathway for oxygen. A similar ternary system was reported by Nouri et al. [68] who utilized MMT and $\mathrm{CuO}$ as dual nanofillers in $\mathrm{CS}$. The addition of $3 \% \mathrm{w} / \mathrm{w}$ MMT-CuO nanoparticles into the CS film increased the tensile strength and elongation at break values by $58.5 \%$ and $52.4 \%$, respectively. Meanwhile, the water vapor permeability and oxygen permeability dropped by $55 \%$ and $32 \%$. To improve the interaction between MMT and CS, Moghadas et al. [69] treated MMT with chitosan sulfate to produce biofunctionalized MMT (SMMT). 


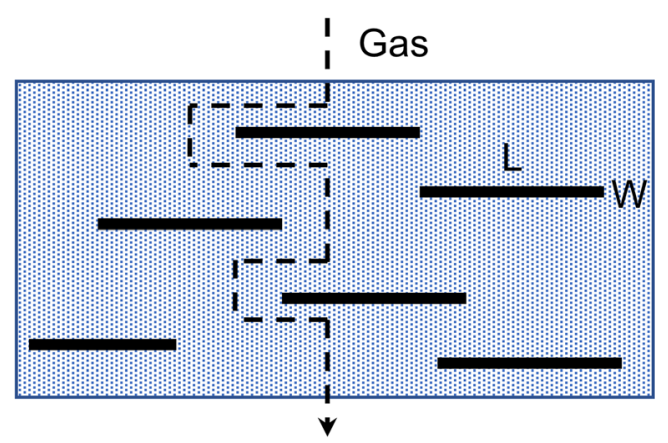

Fig. 4 The tortuous patch for gas transfer in a composite with a high aspect ratio filler

Compared to the tensile strength (16.3 MPa) and Young's modulus (548 MPa) of CS film, the CS/SMMT composite film showed a value of $19.4 \mathrm{MPa}$ for tensile strength and $1178 \mathrm{MPa}$ for Young's modulus, which was also higher than the results of CS/MMT film (18.15 MPa for tensile strength, 1033.45 MPa for tensile modulus). Most importantly, the CS/ SMMT film exhibited the best barrier properties for moisture vapor transmission which was $20 \%$ and $10 \%$ lower than CS and CS/MMT film, respectively.

\subsubsection{Metal/metal oxide particles}

Metal- or metal-oxide particles materials are incorporated into polymers to enhance the mechanical, thermal, and barrier properties. While these may be viewed as deleterious to endof-life, we mention them here because their presence in small quantities in compost or landfill may be tolerable. Indumathi et al. [70] prepared chitosan (CS)-cellulose acetate phthalate (CAP)-based composite films with $\mathrm{ZnO}$ particles. At $5 \mathrm{wt} \%$ $\mathrm{ZnO}$, the composite films showed the highest improvement in tensile strength, a 90\% increase compared to the neat CS-CAP films. Under the same loading, both WVTR and OTR decreased by $68 \%$ and $15 \%$, respectively. The $\mathrm{ZnO}$ also improved the antimicrobial activity of the composite films. The antibacterial properties of $\mathrm{CNC}$ films containing $\mathrm{ZnO}, \mathrm{TiO}_{2}$, and $\mathrm{Ag}_{2} \mathrm{O}$ were investigated [71]. The $\mathrm{CNC} / \mathrm{Ag}_{2} \mathrm{O}$ composite films exhibited the best antibacterial activity both at shorter and longer incubation times on Escherichia coli cells compared to $\mathrm{CNCs} / \mathrm{ZnO}$ and $\mathrm{CNCs} / \mathrm{TiO}_{2}$. A range of other metal or metal oxide particles that have also combined with chitosan, cellulose, and starch are the typical examples to improve the packaging-relevant properties [72-78].

\subsubsection{Cellulose and chitin as fillers}

Cellulose nanomaterials have been widely investigated as a filler to improve the intrinsic properties of petroleum-based materials and other biobased packaging materials. Azeredo et al. [79] added CNC to mango puree solution and showed that compared to neat mango-puree film, the tensile strength and elastic modulus of the film with 0.36 g-CNF/g-dry-mango-puree increased from 4.09 to $8.76 \mathrm{MPa}$ and from 19.9 to $322 \mathrm{MPa}$, respectively, and the water vapor permeability decreased from 63.8 to $40.1 \mathrm{~g} \mathrm{~mm} \mathrm{~m}^{-2} \mathrm{day}^{-1} \mathrm{kPa}^{-1}$. Battegazzore et al. [80] fabricated poly(lactic acid) (PLA)-based films with $30 \mathrm{wt} \%$ of cellulose that had an oxygen permeability (OP) of $110 \mathrm{~cm}^{3} \mu \mathrm{m} \mathrm{m}^{-2}$ day $^{-1} \mathrm{kPa}^{-1}, 63 \%$ lower than the neat PLA film. Li et al. [33] prepared ChNW-reinforced polypropylene (PP) in which water vapor permeance decreased from $\sim 3.7 \times$ $10^{-8}$ to $\sim 1.0 \times 10^{-8} \mathrm{~g} \mathrm{~m}^{-2} \mathrm{~s}^{-1} \mathrm{~Pa}^{-1}$ for the film with $1 \mathrm{wt} \%$ of ChNWs and compared to neat PP.

\subsection{Coating}

\subsubsection{Single-layer coatings}

Beyond neat films, it is possible to apply these nanomaterials as coatings to enhance OP of other substrates. Li et al. [29] coated a thin layer $(1.5 \mu \mathrm{m})$ of CNCs on four different substrates, including PET, oriented PP, oriented polyamide, and cellophane, resulting in $>99 \%$ reduction of oxygen permeance at $23{ }^{\circ} \mathrm{C}$ and $0 \% \mathrm{RH}$. The water vapor permeance decreased $22,26,24$, and $6.5 \%$ at $38{ }^{\circ} \mathrm{C}$ and $100 \% \mathrm{RH}$, respectively. Fukuzumi et al. [54] coated TEMPO-oxidized CNF of three different average lengths $(200,680,1100 \mathrm{~nm})$ on PET and PLA, and the OP values were $\sim 2$ and $>3$ orders of magnitude lower than the neat substrates at $23{ }^{\circ} \mathrm{C}$ and $0 \%$ $\mathrm{RH}$, respectively. The OP increased with an increasing RH. In addition, the films coated with longer fibers had lower OP, but the improvement diminished as the RH increased. Fan et al. [24] obtained three different types of ChNW by deacetylation, acid hydrolysis, and TEMPO-oxidation, respectively. ChNF was also prepared from squid pens. By casting ChNW or ChNF on PLA film, the OP of the films decreased from 184 to $\sim 1 \mathrm{~cm}^{3} \mu \mathrm{m} \mathrm{m}^{-2} \mathrm{day}^{-1} \mathrm{kPa}^{-1}$ at $23^{\circ} \mathrm{C}$ and $0 \% \mathrm{RH}$.

\subsubsection{Multilayer coatings}

To meet the high requirements for barrier properties concerning water vapor and oxygen, the formation of a multilayer coating structure is often necessary. Biopolymer coatings with high oxygen barrier properties can be combined with a hydrophobic top coating layer to give the required water vapor barrier properties [81]. Figure 5 exhibits a typical schematic structure of a multilayer coating, where the additional functional layer can provide certain properties, like antimicrobial ability or printability.

Layer-by-layer (LBL) assembly is one of the simplest and most applicable methods for multilayer coating preparation. This technique allows the formation of controllable nano- or micro-scale thin films through the alternate deposition of oppositely charged polyelectrolytes or particles on the substrate film surface. LBL multilayer coatings can be assembled using 


\begin{tabular}{|c|}
\hline Functional layer \\
\hline Water vapor barrier \\
\hline Gas barrier/Grease barrier \\
\hline Film substrate \\
\hline Printing layer (graphic) \\
\hline
\end{tabular}

Fig. 5 Typical multilayer coating structure [81]

different techniques like dipping, spraying, or spinning methods [82].

Chitin and cellulose nanoparticles, because they carry opposite charges, can be used to create a multilayered sustainable coating layer. Satam et al. [16] demonstrated the successful layer-by-layer spray coating of cationic $\mathrm{ChNFs}$ and anionic CNCs suspension onto poly(lactic acid) (PLA) film. Multilayers of ChNF/CNC coatings on PLA showed a synergistic effect where they presented a lower OP than those coated with $\mathrm{ChNF}$ or $\mathrm{CNC}$ alone. With the three alternating layers (ChNF-CNC-ChNF) structure, the composite film exhibited the highest oxygen barrier property which was $73 \%$ lower than PLA film. However, when the relative humidity increased to higher than $80 \%$, the oxygen permeability of the ChNF-CNC multilayer approached the range of values displayed by neat PLA film. This can be attributed to the fact that the polysaccharide-based coating is sensitive to moisture. This was also reflected in the WVTR results, in which the multilayer films presented a WVTR in the range of 64$150 \mathrm{~g} \mathrm{~m}^{-2}$ day $^{-1}$, similar to neat PLA, even after coating with up to 5 alternating layers of $\mathrm{ChNF}$ and $\mathrm{CNC}$. Li et al. [58] prepared alternating $\mathrm{CS}$ and $\mathrm{CNC}$ coatings onto PET substrate through dip-coating. For 30 bilayers (CS/CNCs), the oxygen permeability value of the coated PET was reduced by $94 \%$, compared to the uncoated PET sample, from 0.2 down to about $0.013 \mathrm{~cm}^{3} \mathrm{~m}^{-2} 24 \mathrm{~h}^{-1} \mathrm{kPa}^{-1}$. This improvement was related to strong electrostatic interaction and hydrogen bonding between CS and CNCs. The author also pointed out that for the multilayer coating, the OP was reduced only as the number of layers exceeded a threshold value, which was 5 for $\mathrm{CS} / \mathrm{CNC}$ coatings. The most significant decrease in oxygen permeability value was observed from 5 to 10 bilayer. In the first 5 bilayers, some pores or extremely thin coating parts resulted in facile oxygen permeation. When the number of coating layers rose to 10 , a fully covered surface, with several small $\mathrm{CS} / \mathrm{CNC}$ aggregates, was apparent from AFM images. To improve the moisture barrier properties for chitin or cellulose-based multilayer coating on paper, Li et al. [83] prepared polymer-nanoclay hybrid multilayers consisting of quad-layers $(\mathrm{QL})$ of carrageenan $(\mathrm{CR}) / \mathrm{CS} / \mathrm{MMT} / \mathrm{CS}$ through LBL assembly. The original paper had a high WVTR value of $2903 \mathrm{~g} \mathrm{~m}^{-2}$ day $^{-1}$, which was attributed to the porous structure of cellulose fiber networks and hydrophilic characteristics. With the addition of the MMT layer, the water molecules must transfer through the impermeable MMT clay platelets by rerouting their path, thereby leading to a significant drop in WVTR. The barrier property was further enhanced with a wax treatment on the top surface layer of the coating. The WVTR gradually decreased along with the growing number of QLs. The WVTR of the composite film with a wax-modified (CR/ $\mathrm{CS} / \mathrm{MMT} / \mathrm{CS})_{1}$, wax-modified (CR/CS/MMT/CS $)_{2}$, and waxmodified $(\mathrm{CR} / \mathrm{CS} / \mathrm{MMT} / \mathrm{CS})_{3}$ multilayer reduced to 1723 , 879 and $418 \mathrm{~g} \mathrm{~m}^{-2}$ day $^{-1}$, respectively, which represented a $33.1 \%, 65.9 \%$, and $83.8 \%$ reduction compared to the control sample.

\subsection{Blends of cellulose and chitin}

Both chitin and cellulose nanomaterials have excellent mechanical and barrier properties when they are separately applied. However, only limited studies on blends of cellulose and chitin have also been reported, and only a subset of these report barrier properties. $\mathrm{NaOH} /$ urea [84], $\mathrm{NaOH}$ /thiourea [85], and $\mathrm{NaOH} /$ thiourea/urea [86] have been applied to directly dissolve chitin and cellulose followed by blending the solutions and coagulating to form a film. The breaking elongation of the blend was lower than the neat cellulose film [84, 86], but tensile strength increased with increasing content of cellulose [84]. Duan et al. [23] dissolved cellulose and chitin with an ionic liquid and $\gamma$-valerolactone and prepared films by removing the solvent using ethanol. The maximum tensile strength, elastic modulus, and breaking elongation were obtained at $80 \mathrm{wt} \%$ chitin, at $4.7 \mathrm{MPa}, 27.4 \mathrm{MPa}$, and $78.7 \%$, respectively. Robles et al. [87] blended CNF and ChNC suspensions and prepared self-standing films. WVTR decreased from 102 to $79 \mathrm{~g} \mathrm{~mm} \mathrm{~m}^{-2}$ day $^{-1}$ as the content of ChNC increased from 0 to $10 \%$. Satam et al. [30] blended ChNF and $\mathrm{CNC}$ suspension and obtained film by casting. The sample with 25 wt $\%$ of $\mathrm{ChNF}$ had an OP of $1.7 \mathrm{~cm}^{3} \mu \mathrm{m} \mathrm{m}^{-2}$ day $^{-1} \mathrm{kPa}^{-1}$, which was $91 \%$ lower than the $\mathrm{OP}$ of the neat $\mathrm{CNC}$ film.

\subsection{Alignment control}

Referring to the polymer composite film, alignment control refers to both alignment of fillers and the alignment of the polymer matrix. Several publications reported that aligned fillers, such as graphene oxide nanosheets [88], vermiculite (VMT) clay [89], boron nitride nanosheets [90], and layered double hydroxide (LDH) [91], showed improvements in various properties compared to randomly oriented ones. For aligned polymer matrix, gas barrier properties also exhibit an enhancement due to improved crystallinity and lower free volume, which creates more resistance to the diffusion of gas molecules. The building blocks for chitin or cellulose 
coating films are chitin or cellulose nanocrystals or nanofibers. The Langmuir-Blodgett technique, evaporationinduced assembly, external field assistant assembly, microfluidic flow method, electrospinning, and mechanical force-induced alignment are commonly used methods to orient high aspect structures such as nanowires [92]. Because of their similar geometry, these techniques should also be capable of adjusting the anisotropy of chitin or cellulose nanocrystals or nanofibers. In particular, mechanical force is relatively simple. Contact-printing [93, 94], knocking-down [95], and the strain-release assembly [96] are some typical methods based on this mechanism. Aligned chitin or cellulose structures have been obtained with the aid of the abovementioned techniques, which are used to enhance mechanical properties and thermally conductivity [97-99]. However, limited publications report aligned neat cellulose or chitin films and coatings for sustainable packaging applications. Recently, Chowdhury et al. [28] used rod-coating to prepare pristine nanocellulose films with controlled anisotropy. The free volume of the film was controlled by the anisotropy of the nanocellulose, which led to an effective adjustment of the gas diffusion path. A 900-fold and 40-fold reduction in $\mathrm{O}_{2}$ and $\mathrm{CO}_{2}$ transport rates were obtained for the highest anisotropy cellulose film as compared to the isotropic case. Further, the best-aligned cellulose films exhibited a 97 and 27 times enhancement in oxygen barrier properties compared to traditional PET and EVOH films, respectively. Another work by Chowdhury et al. [100] showed the same trend between the anisotropy and barrier properties in cellulose-based composite coatings prepared using a roll-to-roll method. The coating layer with the maximum order parameter, 0.78 , gave a reduction of 52\% in WVTR. Because of the relatively low surface charge density and larger aspect ratio for chitin nano-whiskers, compared to cellulose nanocrystals, it may be more difficult to use shear force to prepare aligned pure chitin film. However, the potential for application of aligned chitin film as a barrier packaging material remains largely unexplored.

\section{Biodegradability and recyclability}

\subsection{Biodegradability}

Cellulose- and chitin-based materials have been shown to have low gas permeabilities, which are close to or exceed the barrier properties of traditional packaging materials [37, 101]. Another advantage of cellulose- and chitin-based materials over the common petroleum-based plastics for packaging is their biodegradability. They can degrade in the presence of microorganisms or are susceptible to hydrolysis. Thus, cellulose and chitin present opportunities for reducing the landfill utilization and environmental accumulation of plastic.

\subsubsection{Degradability versus biodegradability}

Degradation is a process in which materials undergo changes in the chemical structure under specific environmental conditions leading to a significant loss in physical and mechanical properties as defined by the American Society for Testing of Materials (ASTM) and International Standards Organization (ISO) [102]. Terms like "oxo," [103-107] "hydro," [39] "photo," [108-110] and "chemo" [111] degradable describe abiotic mechanisms of degradation [112]. These processes do not constitute or represent biodegradability, in which microorganisms are present. However, in the whole biodegradation process, environmental degradation through such processes occurs first or concomitantly with biological degradation. The general mechanism of biodegradation of polymers is shown in Fig. 6. With the help of different types of intracellular and extracellular enzymes produced by bacteria, fungi, and algae, the polymer is converted into water, carbon dioxide, and biomass under aerobic conditions and hydrocarbons, methane, and biomass under anaerobic conditions.

\subsubsection{Biodegradability standards}

Since biodegradability is an end-of-life option, one must clarify the disposal environment, such as composting conditions, soil environment, marine environment, or anaerobic conditions. There are numerous standards published for biodegradability as shown in Table 2. Among these environmental conditions, soil and compost are mostly taken into consideration due to their high microbial diversity. In biodegradation, multiple factors can affect the speed of the disintegration of polymers. These factors can be grouped into two categories: exposure or environmental conditions (moisture, $\mathrm{pH}$ and temperature, and enzyme characteristics) and polymer characteristics (molecular weight, shape, size, additives, and biosurfactants) [114].

\subsubsection{Biodegradation of cellulose-based materials}

In general, the time scale for the biodegradation strongly depends on the biological conditions. The initial shape, dimension, or the existence of fillers also plays an important role in the speed of biodegradation. The biodegradation of cellulose and its derivatives under different conditions are summarized in Table 3. For instance, Bras et al. [115] extracted cellulose whiskers from bleached sugar cane bagasse Kraft pulp and blended with natural rubber and studied the impact of cellulose whiskers content on the biodegradation of the nanocomposite. They observed a drastic increase in the biodegradation rate with increasing content of cellulose whiskers as compared to neat natural rubber. The net weight loss of natural rubber was $19 \%$ after 4 weeks and $62 \%$ and $71 \%$ for composites containing $7.5 \%$ and $12.5 \%$ of cellulose whiskers, 
Fig. 6 General mechanism of biodegradation of polymers [113]

$$
\mathrm{CO}_{2}, \mathrm{H}_{2} \mathrm{O}, \mathrm{CH}_{4}
$$

Other metabolic products

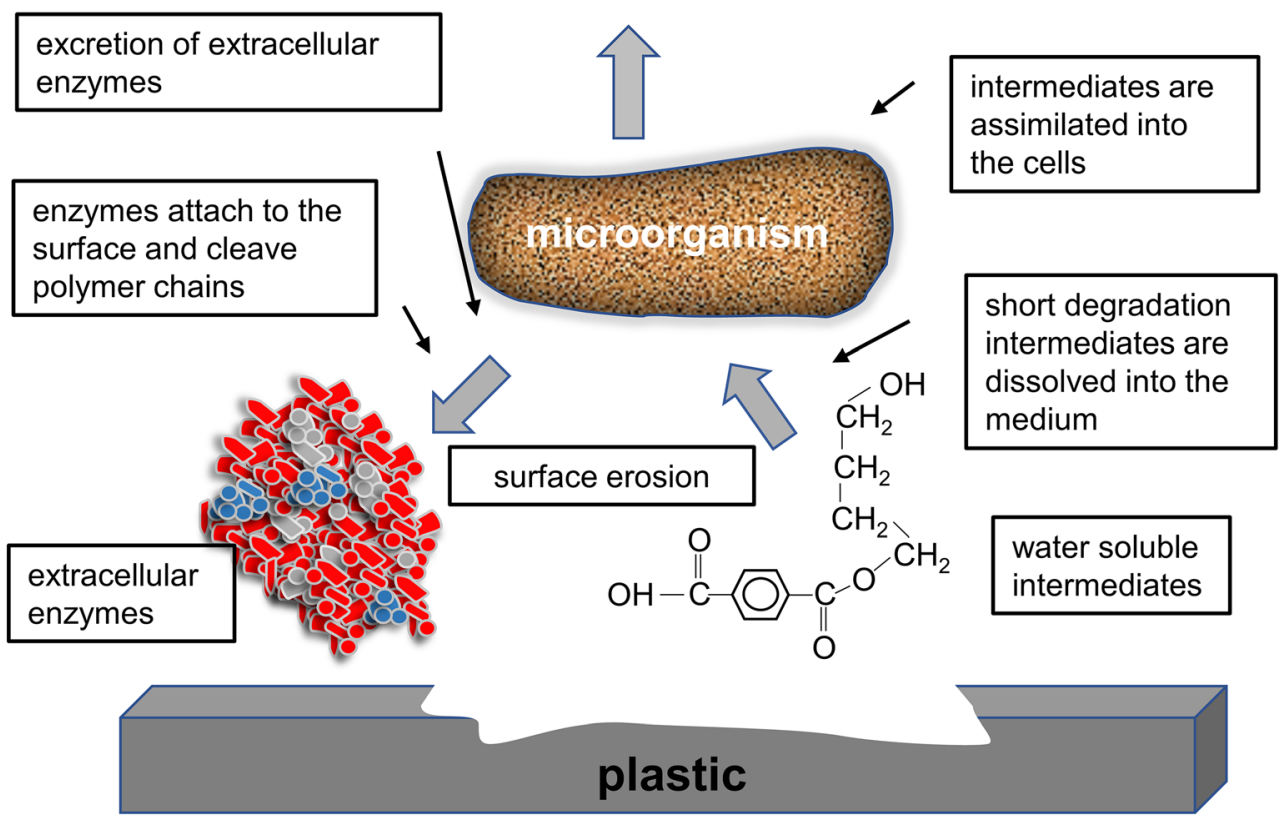

Table 2 Standards for biodegradability (adapted and modified from Ref. [19])

\begin{tabular}{|c|c|c|}
\hline Standard & Description & Disposal condition \\
\hline ASTM D5338 & $\begin{array}{l}\text { Standard test method for determining aerobic biodegradation of plastic materials under controlled } \\
\text { composting conditions }\end{array}$ & Compost \\
\hline ASTM D6400 & Standard specification for compostable plastics & Compost \\
\hline ISO 14855-2:2018 & $\begin{array}{l}\text { Determination of the ultimate aerobic biodegradability of plastic materials under controlled composting } \\
\text { conditions - method by analysis of evolved carbon dioxide - part 2: gravimetric measurement of carbon } \\
\text { dioxide evolved in a laboratory-scale test }\end{array}$ & Compost \\
\hline ISO 20200:2015 & $\begin{array}{l}\text { Determination of the degree of disintegration of plastic materials under simulated composting conditions in } \\
\text { a laboratory-scale test }\end{array}$ & Compost \\
\hline EN 13432:2000 & $\begin{array}{l}\text { Requirements for packaging recoverable through composting and biodegradation. Test scheme and } \\
\text { evaluation criteria for the final acceptance of packaging }\end{array}$ & Compost \\
\hline ASTM D6002-96 & Standard guide for assessing the compostability of environmentally degradable plastics & Compost \\
\hline ISO 17088:2012 & Specifications for compostable plastics & Compost \\
\hline ASTM D5988 & $\begin{array}{l}\text { Standard test method for determining aerobic biodegradation in soil of plastic materials or residual plastic } \\
\text { materials after composting }\end{array}$ & Soil \\
\hline ISO 17556:2019 & $\begin{array}{l}\text { Determination of the ultimate aerobic biodegradability of plastic materials in soil by measuring the oxygen } \\
\text { demand in a respirometer or the amount of carbon dioxide evolved }\end{array}$ & Soil \\
\hline ISO 9439 & $\begin{array}{l}\text { Evaluation of ultimate aerobic biodegradability of organic compounds in an aqueous medium - carbon } \\
\text { dioxide evolution test }\end{array}$ & Aqueous condition \\
\hline ISO 14852 & $\begin{array}{l}\text { Determination of the ultimate aerobic biodegradability of plastic materials in an aqueous medium - method } \\
\text { by analysis of evolved carbon dioxide }\end{array}$ & Aqueous condition \\
\hline ASTM D6691-17 & $\begin{array}{l}\text { Standard test method for determining aerobic biodegradation of plastic materials in the marine environment } \\
\text { by a defined microbial consortium or natural seawater inoculum }\end{array}$ & Marine \\
\hline ASTM D6692-01 & $\begin{array}{l}\text { Standard test method for determining the biodegradability of radiolabeled polymeric plastic materials in } \\
\text { seawater }\end{array}$ & Marine \\
\hline ISO 18830:2016 & $\begin{array}{l}\text { Determination of aerobic biodegradation of non-floating plastic materials in a seawater/sandy sediment } \\
\text { interface - method by measuring the oxygen demand in a closed respirometer }\end{array}$ & Marine \\
\hline ASTM D7081-05 & Standard specification for non-floating biodegradable plastics in the marine environment & Marine \\
\hline ISO 15314:2018 & $\begin{array}{l}\text { Methods for marine exposure containing three methods for the exposure of plastics in a marine } \\
\text { environment }\end{array}$ & Marine \\
\hline ASTM D7081-05 & Standard specification for non-floating biodegradable plastics in the marine & Marine \\
\hline ISO 16221:2001 & Water quality_-guidance for determination of biodegradability in the marine environment & Marine \\
\hline
\end{tabular}


Table 3 Biodegradation of materials involving cellulose and its derivatives

\begin{tabular}{|c|c|c|c|c|c|c|}
\hline Materials & Type of environment & Conditions & $\begin{array}{l}\text { Measurement } \\
\text { method }\end{array}$ & $\begin{array}{l}\text { Biodegradation } \\
(\%)\end{array}$ & $\begin{array}{l}\text { Period of } \\
\text { biodegradation } \\
\text { (days) }\end{array}$ & Ref. \\
\hline Seaweed $/ 5 \%(\mathrm{w} / \mathrm{w})$ cellulose & Soil & $\begin{array}{l}30-50 \% \mathrm{RH}, \\
\text { room T }\end{array}$ & Weight loss & 45 & 14 & [116] \\
\hline CMC/gelatin/chitosan (3/1/1) & Soil & Aerobic, $60^{\circ} \mathrm{C}$ & Weight loss & 56 & 7 & [117] \\
\hline $\begin{array}{l}\text { Cellulose acetate (CA) (produced } \\
\text { from fiber flax) }\end{array}$ & $\begin{array}{l}\text { Municipal solid waste } \\
\text { mixture }\end{array}$ & - & Weight loss & 44 & 14 & [118] \\
\hline CA (produced from cotton linters) & $\begin{array}{l}\text { Municipal solid waste } \\
\text { mixture }\end{array}$ & - & Weight loss & 35 & 14 & [118] \\
\hline 1. Natural rubber (NR) & Soil & $22-25^{\circ} \mathrm{C}$, & Weight loss & $1.19 \%$ & 28 & [115] \\
\hline $\begin{array}{l}\text { 2. } 12.5 \%(\mathrm{w} / \mathrm{w}) \text { cellulose whiskers/NR } \\
\text { nanocomposites }\end{array}$ & & $70-80 \% \mathrm{RH}$ & & $2.71 \%$ & & \\
\hline Cellulose nanoparticle/PVA & Soil & $\begin{array}{l}30-35^{\circ} \mathrm{C} \\
25 \% \mathrm{RH} \\
\mathrm{pH}=7\end{array}$ & Weight loss & - & 21 & [119] \\
\hline $\begin{array}{l}\text { Bacterial cellulose (BC)/guar } \\
\text { gum/PVP-CMC }\end{array}$ & Soil & $\begin{array}{l}30{ }^{\circ} \mathrm{C} \\
68-70 \% \mathrm{RH} \\
\mathrm{pH}=7.59\end{array}$ & Weight loss & & 28 & [120] \\
\hline BC/guar gum/PVP-CMC & Soil & $\begin{array}{l}30{ }^{\circ} \mathrm{C} \\
68-70 \% \mathrm{RH} \\
\mathrm{pH}=7.59\end{array}$ & Weight loss & & 28 & [120] \\
\hline
\end{tabular}

respectively. The authors argued that the faster degradation of the cellulose component led to increased porosity, void formation, and loss of integrity of the natural rubber matrix, and therefore, it resulted in an overall faster disintegration of nanocomposites film containing cellulose whiskers than pure rubber film.

\subsubsection{Biodegradation of chitin-based materials}

The biodegradation of chitin and its derivatives under different conditions are summarized in Table 4. Pavoni et al. [131] studied the impact of crosslinking on the biodegradability of chitosan films under composting. Glutaraldehyde was used as a crosslinking agent between 0.5 and $10 \%$ based on chitosan mass. One percent $(\mathrm{v} / \mathrm{v})$ of acetic acid or lactic acid was used for chitosan solubilization. Biodegradability assessed by visual inspection was performed under aerobic conditions at ambient temperature. No impact on the biodegradability of chitosan was found using lactic acid or acetic acid. Crosslinked films made of both acids presented, for the highest glutaraldehyde content, a more unbroken structure after 28 days, affecting the time of biodegradation. However, even if the biodegradation of the latter was slowed down due to the chemical modification, the film's biodegradable feature remained considering the conditions listed in ISO 20,200:2015 (at least $90 \%$ of the sample is disintegrated before 84 days).

Mohd Asri et al. [126] investigated three types of ChNWs for reinforcement of PLA film for packaging applications. Soil burial test was conducted using garden soil to study biodegradation of the composites in natural conditions.
Biodegradability as indicated by weight loss was faster for all composites compared to that of pure PLA. The authors attributed this faster biodegradation to the presence of chitin material at the surface of the samples which attracted chitinolytic microorganisms such as fungi to consume this material as a nutrient source. In addition, the authors reported increased biodegradation with increasing filler content with the highest weight loss at $4 \mathrm{phr}$ for all chitin types. Commercial chitin-based PLA exhibited the highest weight loss (3.29\%) and fermented chitin-based PLA had the lowest $(2.28 \%)$ after 56 days. This observation was attributed to the higher degree of purity of commercial chitin.

Suriyatem et al. [129] studied the impact of the addition of carboxymethyl chitosan $(\mathrm{CMCh})$ into the rice starch-based film on its biodegradability. They showed that biodegradation, measured by the respirometry method, of the rice starch-based film was slower than biodegradation of pure rice starch film due to lower molecular weight and the presence of more hydroxyl groups. The blend of 50\% (w/w) $\mathrm{CMCh} /$ rice starch exhibited in between biodegradation compared to pure components.

\subsection{Recyclability}

The growing production of biobased packaging materials is also accompanied by an accumulation of biobased waste. The waste management options for biobased polymers need to be discussed and legislated just like those for petroleum-based materials. The biodegradation rate for biodegradable polymers depends on the end-of-life options and physical-chemical 
Table 4 Biodegradation of materials involving chitin and its derivatives

\begin{tabular}{|c|c|c|c|c|c|c|}
\hline Materials & $\begin{array}{l}\text { Type of } \\
\text { environment }\end{array}$ & Conditions & Measurement method & $\begin{array}{l}\text { Biodegradation } \\
(\%)\end{array}$ & $\begin{array}{l}\text { Period of } \\
\text { biodegradation } \\
\text { (days) }\end{array}$ & Ref. \\
\hline $\mathrm{ChNFs} / \mathrm{CNFs}$ & Soil & Humid conditions & Visual inspection & 100 & 7 & [121] \\
\hline Chitin/PVA/nano-silica fibers & Soil & - & Weight loss & $52 \%$ & 30 & {$[122]$} \\
\hline Chitosan & Compost & $\begin{array}{l}25^{\circ} \mathrm{C}, 70-80 \% \\
\mathrm{RH}\end{array}$ & Weight loss & $\sim 55 \%$ & 20 & [123] \\
\hline Chitosan & Soil & Ambient & Weight loss & $27 \%$ & 21 & [124] \\
\hline $\begin{array}{l}\text { Chitosan } / 5 \%(\mathrm{w} / \mathrm{w}) \text { Chinese } \\
\text { chive root extract }\end{array}$ & Soil & Ambient & Weight loss & $47.3 \%$ & 21 & [124] \\
\hline PVA/chitosan & Soil & - & Weight loss & $86 \%$ & 30 & [125] \\
\hline Chitosan and chitosan/starch & Compost & $\begin{array}{l}69.2 \% \mathrm{RH}, \text { room } \\
\mathrm{T}, \mathrm{pH} \sim 8.6\end{array}$ & Visual inspection & $100 \%$ & 20 & [123] \\
\hline $5 \%(\mathrm{w} / \mathrm{w}) \mathrm{ChNWs} / \mathrm{PLA}$ & Soil & $\begin{array}{l}\text { Garden soil } \\
\mathrm{pH} \sim 6-6.5\end{array}$ & Weight loss & $\begin{array}{l}0.88 \% \\
3.29 \%\end{array}$ & 56 & [126] \\
\hline Chitosan/starch & Soil & $\begin{array}{l}69.2 \% \mathrm{RH} \\
\mathrm{pH} \sim 8.6\end{array}$ & Visual inspection & - & 40 & [127] \\
\hline $\begin{array}{l}\text { Chitosan/starch/9\% (w/w) } \\
\text { pineapple leaf microfibers }\end{array}$ & Soil & - & Weight loss & $>80 \%$ & 30 & [128] \\
\hline Chitosan nanoparticles/PVA & Soil & $\begin{array}{l}30-35^{\circ} \mathrm{C} \\
25 \% \mathrm{RH} \\
\mathrm{pH}=7\end{array}$ & Weight loss & - & 21 & [119] \\
\hline $\begin{array}{l}\text { Chitosan and cellulose } \\
\text { nanoparticles/PVA }\end{array}$ & Soil & $\begin{array}{l}30-35^{\circ} \mathrm{C} \\
25 \% \mathrm{RH} \mathrm{pH}=7\end{array}$ & Weight loss & - & 21 & [119] \\
\hline Carboxymethyl chitosan (CMCh) & Compost & $\begin{array}{l}50 \% \mathrm{RH} \\
58{ }^{\circ} \mathrm{C}\end{array}$ & $\begin{array}{l}\% \text { mineralization } \\
\text { (ASTM D5338-15) }\end{array}$ & $40 \%$ & 87 & [129] \\
\hline 1:1 CMCh/rice starch & Compost & $\begin{array}{l}50 \% \mathrm{RH} \\
58{ }^{\circ} \mathrm{C}\end{array}$ & $\begin{array}{l}\% \text { mineralization } \\
\text { (ASTM D5338-15) }\end{array}$ & $60 \%$ & 87 & [129] \\
\hline $\begin{array}{l}\text { 1:1 } \mathrm{CMCh} / \text { rice starch + propolis } \\
\text { extract }(10 \% \mathrm{w} / \mathrm{w})\end{array}$ & Compost & $\begin{array}{l}50 \% \mathrm{RH} \\
58{ }^{\circ} \mathrm{C}\end{array}$ & $\begin{array}{l}\% \text { mineralization } \\
\text { (ASTM D5338-15) }\end{array}$ & $\begin{array}{l}92.2 \% \text { of the cellulose } \\
\text { (positive control) }\end{array}$ & 87 & [130] \\
\hline
\end{tabular}

conditions. Currently, the main waste treatment options for biodegradable polymers are recycling, incineration, landfill, and biological methods (composting and anaerobic digestion). Most commercial biodegradable products degrade slowly under ordinary conditions, even in the presence of microorganisms. This means that large amounts of biobased disposal may create environmental issues in the future. Biodegradable waste disposed into landfills can lead to methane emissions (under anaerobic conditions) with a negative climate impact. Composting is an accelerated degradation process involving mixed organisms. However, many composting facilities address only garden waste because the separation of biodegradable and compostable materials from conventional polymers is a highly cost process. Therefore, recycling may be a preferred option for managing bioplastics, which can reduce the consumption of renewable resources needed for the synthesis of corresponding monomers. Furthermore, bioplastic waste could become an alternative feedstock for monomers and intermediates. The adoption of different recycling techniques (mechanical recycling, chemical recycling, and biological recycling) depends on the properties of biobased polymers, the capacity of the facilities, the economic benefits, and the required performance for the products.
Cellulose, chitin/chitosan, and their derivatives are recognized as versatile biobased packaging materials because of their diverse biological properties (biocompatibility, biodegradability, nontoxicity, antimicrobial properties, antioxidant activity, less immunogenic, and non-hemolytic compared to protein) [132] and superior physical properties (high surface area, good mechanical and barrier properties), and they can be easily assembled into different forms and shapes (powders, fibers, films, beads, sponges, gel, and solutions) [133]. Accompanied by the growing production and application, the related wastes are accumulating. However, few publications investigate the recyclability of chitin and cellulose-based packaging films or coatings, and fewer related industrial plants have been built up for identification, separation, and recycling of these polysaccharide-based wastes. Currently, the recycling process for cellulose-paper-based packaging is relatively well developed. Therefore, we will discuss it briefly to provide context for understanding how cellulosic or chitinbased packaging film might also be incorporated into recycling. However, considerable research and development remain to evaluate the potential feasibility of recycling dense films composed of cellulose or chitin nanomaterials or their blends and multilayers. 
Waste paper, boxes, and cartons are collected, sorted, baled, and transported into the facility to produce pulp. After the deinking process, the pulp is ready to be manufactured into paper and related products in mills similar to production direct from wood pulp [134]. Corrugated boxes obtained a recycling rate of over $88 \%$, for example [135]. There is a need to expand to more methods to re-utilize the waste paper. Several attempts have been made, such as biorefinery, construction and manufacturing, molded paper, fuel, art, and handicraft [134] to produce value-added products. Oliva et al. [136] converted waste paper into value-added cellulose films through rapid dissolution in a pre-cooled $\mathrm{H}_{2} \mathrm{SO}_{4}$ solution. The regenerated cellulose films were transparent and had comparable mechanical properties to those cellulose films prepared from the spruce pulp in the same solvent. Martínez-Barrera et al. [137] obtained the recycled cellulose fiber and incorporated it into polyester-based composites. The flexural strength and modulus improved by $13 \%$ and $19 \%$ with $1 \mathrm{wt} \%$ irradiated recycled cellulose fiber, respectively. The enzymatic hydrolysis of waste paper to produce a liquid biofuel was investigated by Brummer et al. [138] With the help of the enzyme NS50013, the yield of biofuel from cardboard and recycled paper reached $24.4 \%$ and $23.0 \%$, respectively. Apart from the paper industry, the recycling of other cellulose and chitinbased packaging materials is less developed and investigated. However, the application of these materials is growing at a rapid pace. Cellulose and chitin have been widely used as the fillers or coatings for other biobased polymers, like PLA and PHA, and even some petroleum-based plastics to improve their biodegradability. Efficient techniques to separate the biodegradable materials from non-biodegradable ones and to sort them into groups based on different recycling methods need to be developed. Further, more efforts are required to improve the techniques and facilities to enable the recycling of various biobased packaging materials.

\section{Conclusions}

There is growing importance in exploring biodegradable materials and advanced technologies to develop sustainable packaging. The use of petroleum-based composite multilayers in packaging applications has raised concerns about landfill use and leakage to the environment due to their long degradation times. Biopolymer-based composites show the potential to gradually replace petroleum-based counterparts. Cellulose and chitin are two of the most abundant natural polymers with promising characteristics as fillers or matrices. Because of their high oxygen barrier properties and mechanical properties, they have been investigated as barrier materials as fillers for other biobased polymers, as neat films, as multilayers, and as blends. However, creating efficient and economically scalable extraction methods, improving compatibility with polymer matrices, and improving the humidity and thermal stability of biobased materials are remaining challenges. To address the scalable production issues, persistent efforts have been made to explore new methods such as biological fermentation [139, 140] and ionic liquid extraction [141-143]. In 2019, an efficient and economical protocol, using hot water for deproteinization and carbonic acid for demineralization, termed the HOW-CA process was described for the fractionation of shrimp shells [144]. Water and $\mathrm{CO}_{2}$ are the only reagents in the process, and the resulting chitin product has a purity of over $90 \%$ [144]. Because of the hydrophilic groups on the backbones, these biobased materials are easily mixed with a water-soluble polymer matrix. In order to broaden the range of polymers available for $\mathrm{CNC} / \mathrm{ChNF}$-reinforcement, surface modifications are widely applied. Covalent modification (esterification, silylation, polymer grafting) and noncovalent modification (polyelectrolytes, surfactants) are applied to improve the compatibility between biobased fillers and polymer matrix [145-147]. Chemical pretreatments such as carboxymethylation and TEMPO have been applied to lower energy consumption for the production of CNFs [148, 149], while the CNCs are generally isolated from cellulose with a controlled hydrolysis process involving sulfuric acid. However, functional groups (carboxyl, carboxymethyl, and sulfate groups) are often introduced during these processes and can deteriorate the thermal stability of cellulose-based materials, particularly for sulfate groups. Graft copolymerization and alkaline treatment are potential methods to improve thermal stability [150-152]. The alkaline treatment can simultaneously alter the surface chemical structure and condensed physical structure of CNCs in the liquid crystal state. As a result, the crystalline structure of cellulose is converted from form I to form II, and the sulfate groups are eliminated, leading to an improvement in mechanical and thermal properties. Grafting polymer chains onto the surface of cellulose can also lead to the enhancement of thermal stability. One possible explanation is that the polymer chains create a uniform layer that acts as a protective shield on the nanocellulose surface [153]. Recently published works show that increasing the lignin content [154], doping with melamine-grafted nano $\mathrm{SiO}_{2}$ [155], absorption of surfactants [156] all have a beneficial effect on the thermal stability of cellulose nanomaterials. Methods like these provide opportunities to overcome stability and extraction challenges in these biobased materials, which are important issues to consider for scale-up to industrial production of biobased packaging materials.

In addition to being used as fillers, chitin and cellulose have been cast, sprayed, or blade coated into free-standing films or coatings. Incorporation of organic or inorganic fillers, design of multilayer coatings, and modifications of the interface are the most commonly adopted methods to improve the properties of chitin or cellulose-based films. Because of the opposite surface charges, recent research focuses on combining chitin 
and cellulose to produce biomass-derived biodegradable composite films. They can be blended to fabricate polyelectrolyte complexes or coated as multilayers through layer-by-layer techniques. The composite films show better oxygen barrier properties than either component. Furthermore, combinations of chitin and cellulose can result in materials with antibacterial activity, metal ion adsorption, odor treatment properties, etc. The alignment control is another potential way to improve the gas barrier properties of chitin or cellulose nanocrystal or nanofiber-based films. Many publications have discussed techniques to orient chitin and cellulose. However, limited work evaluates the aligned film for barrier and other properties relevant to packaging applications. Building a relationship between microstructure design and overall barrier properties is essential to developing high-performance sustainable packaging films by using these materials.

There is tremendous potential in the applications of polysaccharide-based films in food packaging. The main efforts focused on investigating the combination of different biobased materials, and the reinforcement effect of various fillers. Selective barrier properties for different gas molecules and adjustable sensitivity to moisture are desireable characteristics based on the specific requirements and transportation conditions of different food products. Further research to enhance the properties of these biodegradable packaging films to obtain properties similar to commercial plastics is essential. Biopolymers have started to receive recognition in multiple industrial sectors; legislation has been put forward to regulate the production and recycling of plastic packaging materials; and public environmental awareness has increased globally. These are all positive drivers for wide-spread adoption of biobased packaging materials. Of course, biopolymers will not replace synthetic plastic all at once, as petroleum-based films are currently less expensive, and most packaging converter facilities are builtfor the processing ofthermoplastics. Nevertheless, chitin and cellulose-based products have been commercialized for other applications in the field of cosmetics, pharmaceuticals, water treatment, and food additives. The market for sustainable packaging is growing continuously and appears to be accelerating. A research strategy that focuses on economic processability and resistance to the effects of water vapor will be required to ensure that the application of cellulose and chitin in sustainable packaging applications will be developed and commercialized.

Acknowledgments We would like to acknowledge Samantha Waters for her contributions to this work.

Authors' contributions The manuscript was written through the contributions of all authors. All authors have given approval to the final version of the manuscript.

Funding This research was supported by the Nestlé and Winpak, Ltd. corporations, as well as through the US Department of Energy Award Number EE0008494.
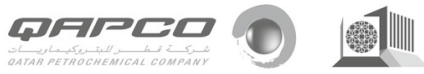

Open Access This article is licensed under a Creative Commons Attribution 4.0 International License, which permits use, sharing, adaptation, distribution and reproduction in any medium or format, as long as you give appropriate credit to the original author(s) and the source, provide a link to the Creative Commons licence, and indicate if changes were made. The images or other third party material in this article are included in the article's Creative Commons licence, unless indicated otherwise in a credit line to the material. If material is not included in the article's Creative Commons licence and your intended use is not permitted by statutory regulation or exceeds the permitted use, you will need to obtain permission directly from the copyright holder. To view a copy of this licence, visit http://creativecommons.org/licenses/by/4.0/.

\section{References}

1. R. Geyer, J.R. Jambeck, K.L. Law, Production, use, and fate of all plastics ever made. Sci. Adv. 3(7), e1700782 (2017)

2. A.H. Tullo, The cost of plastic packaging. Chem. Eng. News 94(41), 33 (2016)

3. A.M. Salaberria, R.H. Diaz, J. Labidi, S.C. Fernandes, Role of chitin nanocrystals and nanofibers on physical, mechanical and functional properties in thermoplastic starch films. Food Hydrocoll. 46, 93-102 (2015)

4. I. Soltani, R.J. Spontak, Nanotechnological strategies yielding high-barrier plastic food packaging in Food Packaging (Academic Press, Cambridge, 2017), pp. 1-43

5. J. Wang, D.J. Gardner, N.M. Stark, D.W. Bousfield, M. Tajvidi, Z. Cai, Moisture and oxygen barrier properties of cellulose nanomaterial-based films. ACS Sustain. Chem. Eng. 6(1), 49-70 (2018)

6. M. Barikani, E. Oliaei, H. Seddiqi, H. Honarkar, Preparation and application of chitin and its derivatives: a review. Iran. Polym. J. 23(4), 307-326 (2014)

7. M.G. Peter, Chitin and Chitosan from Animal Sources, in Polysaccharides II: polysaccharides of eukaryotes, ed. by S. De Baets, E. Vandamme, A. Steinbuchel (Wiley-VCH, Hoboken, 2004), p.481

8. Chitosan Market Size, Share \& Trends Analysis Report By Application (Pharmaceutical \& Biomedical, Water Treatment, Cosmetics, Food \& Beverage), By Region (APAC, North America, Europe, MEA), And Segment Forecasts, 2020-2027, (Grand View Research, 2020). https://www.grandviewresearch. com/industry-analysis/global-chitosan-market. Accessed 31 Aug 2020

9. P. Béguin, J.-P. Aubert, The biological degradation of cellulose. FEMS Microbiol. Rev. 13(1), 25-58 (1994)

10. S. Beier, S. Bertilsson, Bacterial chitin degradation - mechanisms and ecophysiological strategies. Front. Microbiol. 4, 149 (2013)

11. S. Roy, P. Leclerc, F. Auger, G. Soucy, C. Moresoli, L. Côté, D. Potvin, C. Beaulieu, R. Brzezinski, A novel two-phase composting process using shrimp shells as an amendment to partly composted biomass. Compost Sci. Util. 5(4), 52-64 (1997)

12. R.J. Moon, A. Martini, J. Nairn, J. Simonsen, J. Youngblood, Cellulose nanomaterials review: structure, properties and nanocomposites. Chem. Soc. Rev. 40(7), 3941-3994 (2011)

13. S. Ifuku, H. Saimoto, Chitin nanofibers: preparations, modifications, and applications. Nanoscale 4(11), 3308-3318 (2012)

14. S. Belbekhouche, J. Bras, G. Siqueira, C. Chappey, L. Lebrun, B. Khelifi, S. Marais, A. Dufresne, Water sorption behavior and gas barrier properties of cellulose whiskers and microfibrils films. Carbohydr. Polym. 83(4), 1740-1748 (2011) 
15. J. Wu, K. Zhang, N. Girouard, J.C. Meredith, Facile route to produce chitin nanofibers as precursors for flexible and transparent gas barrier materials. Biomacromolecules 15(12), 4614-4620 (2014)

16. C.C. Satam, C.W. Irvin, A.W. Lang, J.C.R. Jallorina, M.L. Shofner, J.R. Reynolds, J.C. Meredith, Spray-coated multilayer cellulose nanocrystal - chitin nanofiber films for barrier applications. ACS Sustain. Chem. Eng. 6(8), 10637-10644 (2018)

17. A. Isogai, R. Atalla, Preparation of cellulose-chitosan polymer blends. Carbohydr. Polym. 19(1), 25-28 (1992)

18. P. Cazon, G. Velazquez, J.A. Ramirez, M. Vazquez, Polysaccharide-based films and coatings for food packaging: a review. Food Hydrocoll. 68, 136-148 (2017)

19. K.E. Helanto, L. Matikainen, R. Talja, O.J. Rojas, Bio-based polymers for sustainable packaging and biobarriers: a critical review. BioRes. 14(2), 4902 (2019)

20. N. Lavoine, I. Desloges, A. Dufresne, J. Bras, Microfibrillated cellulose - its barrier properties and applications in cellulosic materials: a review. Carbohydr. Polym. 90(2), 735-764 (2012)

21. D. Klemm, F. Kramer, S. Moritz, T. Lindström, M. Ankerfors, D. Gray, A. Dorris, Nanocelluloses: a new family of nature-based materials. Angew. Chem. Int. Ed. Eng. 50(24), 5438-5466 (2011)

22. B. Wang, M. Sain, K. Oksman, Study of structural morphology of hemp fiber from the micro to the nanoscale. Appl. Compos. Mater. 14(2), 89-103 (2007)

23. Y.Q. Duan, A. Freyburger, W. Kunz, C. Zollfrank, Cellulose and chitin composite materials from an ionic liquid and a green cosolvent. Carbohydr. Polym. 192, 159-165 (2018)

24. Y. Fan, H. Fukuzumi, T. Saito, A. Isogai, Comparative characterization of aqueous dispersions and cast films of different chitin nanowhiskers/nanofibers. Int. J. Biol. Macromol. 50(1), 69-76 (2012)

25. I. Sakurada, Y. Nukushina, T. Ito, Experimental determination of the elastic modulus of crystalline regions in oriented polymers. J. Polym. Sci. 57(165), 651-660 (1962)

26. J.F. Vincent, U.G. Wegst, Design and mechanical properties of insect cuticle. Arthropod Struct. Dev. 33(3), 187-199 (2004)

27. Y. Bamba, Y. Ogawa, T. Saito, L.A. Berglund, A. Isogai, Estimating the strength of single chitin nanofibrils via sonication-induced fragmentation. Biomacromolecules 18(12), 4405-4410 (2017)

28. R.A. Chowdhury, M. Nuruddin, C. Clarkson, F. Montes, J. Howarter, J.P. Youngblood, Cellulose nanocrystal (CNC) coatings with controlled anisotropy as high-performance gas barrier films. ACS Appl. Mater. Interfaces 11(1), 1376-1383 (2019)

29. F. Li, P. Biagioni, M. Bollani, A. Maccagnan, L. Piergiovanni, Multi-functional coating of cellulose nanocrystals for flexible packaging applications. Cellulose 20(5), 2491-2504 (2013)

30. C.C. Satam, C.W. Irvin, C.J. Coffey, R.K. Geran, R. IbarraRivera, M.L. Shofner, J.C. Meredith, Controlling barrier and mechanical properties of cellulose nanocrystals by blending with chitin nanofibers. Biomacromolecules 21(2), 545-555 (2020)

31. S.M. Mousavi, E. Afra, M. Tajvidi, D. Bousfield, M. DehghaniFirouzabadi, Cellulose nanofiber/carboxymethyl cellulose blends as an efficient coating to improve the structure and barrier properties of paperboard. Cellulose 24(7), 3001-3014 (2017)

32. J.Y. Xia, Z. Zhang, W. Liu, V.C.F. Li, Y.F. Cao, W. Zhang, Y.L. Deng, Highly transparent $100 \%$ cellulose nanofibril films with extremely high oxygen barriers in high relative humidity. Cellulose 25(7), 4057-4066 (2018)

33. S.C.-Y. Li, Y.-C. Sun, Q. Guan, H. Naguib, Effects of chitin nanowhiskers on the thermal, barrier, mechanical, and rheological properties of polypropylene nanocomposites. RSC Adv. 6(76), 72086 (2016)

34. J.S. Sun, Y. Du, J.Q. Ma, Y.Z. Li, L. Wang, Y.Z. Lu, J.W. Zou, J. Pang, C.H. Wu, Transparent bionanocomposite films based on konjac glucomannan, chitosan, and TEMPO-oxidized chitin nanocrystals with enhanced mechanical and barrier properties. Int. J. Biol. Macromol. 138, 866-873 (2019)

35. A.A. Oun, J.W. Rhim, Preparation of multifunctional carboxymethyl cellulose-based films incorporated with chitin nanocrystal and grapefruit seed extract. Int. J. Biol. Macromol. 152, 1038-1046 (2020)

36. M. Martinez-Sanz, A. Lopez-Rubio, J.M. Lagaron, High-barrier coated bacterial cellulose nanowhiskers films with reduced moisture sensitivity. Carbohydr. Polym. 98(1), 1072-1082 (2013)

37. J. Lange, Y. Wyser, Recent innovations in barrier technologies for plastic packaging?a review. Packag. Technol. Sci. 16(4), 149-158 (2003)

38. M. Shimizu, T. Saito, A. Isogai, Water-resistant and high oxygen-barrier nanocellulose films with interfibrillar crosslinkages formed through multivalent metal ions. J. Membr. Sci. 500, 1-7 (2016)

39. V. Siracusa, P. Rocculi, S. Romani, M. Dalla Rosa, Biodegradable polymers for food packaging: a review. Trends Food Sci. Technol. 19(12), 634-643 (2008)

40. K.M. Kjm, J.H. Son, S.K. Kim, C.L. Weller, M.A. Hanna, Properties of chitosan films as a function of $\mathrm{pH}$ and solvent type. J. Food Sci. 71(3), E119 (2006)

41. S. Santacruz, C. Rivadeneira, M. Castro, Edible films based on starch and chitosan. Effect of starch source and concentration, plasticizer, surfactant's hydrophobic tail and mechanical treatment. Food Hydrocoll. 49, 89-94 (2015)

42. A. Gennadios, A.H. Brandenburg, J.W. Park, C.L. Weller, R.F. Testin, Water vapor permeability of wheat gluten and soy protein isolate films. Ind. Crop. Prod. 2(3), 189-195 (1994)

43. M. Osterberg, J. Vartiainen, J. Lucenius, U. Hippi, J. Seppala, R. Serimaa, J. Laine, A fast method to produce strong nfc films as a platform for barrier and functional materials. ACS Appl. Mater. Interfaces 5(11), 4640-4647 (2013)

44. C. Aulin, M. Gallstedt, T. Lindstrom, Oxygen and oil barrier properties of microfibrillated cellulose films and coatings. Cellulose 17(3), 559-574 (2010)

45. I. Siro, D. Plackett, M. Hedenqvist, M. Ankerfors, T. Lindstrom, Highly transparent films from carboxymethylated microfibrillated cellulose: the effect of multiple homogenization steps on key properties. J. Appl. Polym. Sci. 119(5), 2652-2660 (2011)

46. V. Kumar, R. Bollstrom, A. Yang, Q.X. Chen, G. Chen, P. Salminen, D. Bousfield, M. Toivakka, Comparison of nano- and microfibrillated cellulose films. Cellulose 21(5), 3443-3456 (2014)

47. C.N. Wu, T. Saito, S. Fujisawa, H. Fukuzumi, A. Isogai, Ultrastrong and high gas-barrier nanocellulose/clay-layered composites. Biomacromolecules 13(6), 1927-1932 (2012)

48. T.T.T. Ho, T. Zimmermann, S. Ohr, W.R. Caseri, Composites of cationic nanofibrillated cellulose and layered silicates: water vapor barrier and mechanical properties. ACS Appl. Mater. Interfaces 4(9), 4832-4840 (2012)

49. C.S. Wang, J.W. Shi, M. He, L. Ding, S.P. Li, Z.H. Wang, J. Wei, High strength cellulose/ATT composite films with good oxygen barrier property for sustainable packaging applications. Cellulose 25(7), 4145-4154 (2018)

50. D. Enescu, C. Gardrat, H. Cramail, C. Le Coz, G. Sebe, V. Coma, Bio-inspired films based on chitosan, nanoclays and cellulose nanocrystals: structuring and properties improvement by using water-evaporation-induced self-assembly. Cellulose 26(4), 2389-2401 (2019)

51. L.D. Zhang, H.L. Wang, C.Y. Jin, R. Zhang, L.L. Li, X.J. Li, S.T. Jiang, Sodium lactate loaded chitosan-polyvinyl alcohol/ montmorillonite composite film towards active food packaging. Innov. Food Sci. Emerg. Technol 42, 101-108 (2017) 
52. M.S. Rao, S.R. Kanatt, S.P. Chawla, A. Sharma, Chitosan and guar gum composite films: preparation, physical, mechanical and antimicrobial properties. Carbohydr. Polym. 82(4), 12431247 (2010)

53. L.F. Qu, G.Y. Chen, S. Dong, Y.X. Huo, Z.L. Yin, S.H. Li, Y. Chen, Improved mechanical and antimicrobial properties of zein/ chitosan films by adding highly dispersed nano-TiO2. Ind. Crop. Prod. 130, 450-458 (2019)

54. H. Fukuzumi, T. Saito, A. Isogai, Influence of TEMPO-oxidized cellulose nanofibril length on film properties. Carbohydr. Polym. 93(1), 172-177 (2013)

55. B.S. Munteanu, E. Paslaru, L.F. Zemljic, A. Sdrobis, G.M. Pricope, C. Vasile, Chitosan Coatings Applied to Polyethylene Surface to Obtain Food-Packaging Materials. Cellul. Chem. Technol. 48(5-6), 565 (2014)

56. T.H. Zhong, M.P. Wolcott, H. Liu, J.W. Wang, Developing chitin nanocrystals for flexible packaging coatings. Carbohydr. Polym. 226, 115276 (2019)

57. T. Kim, T.H. Tran, S.Y. Hwang, J. Park, D.X. Oh, B.S. Kim, Crab-on-a-tree: all biorenewable, optical and radio frequency transparent barrier nanocoating for food packaging. ACS Nano 13(4), 3796-3805 (2019)

58. F. Li, P. Biagioni, M. Finazzi, S. Tavazzi, L. Piergiovanni, Tunable green oxygen barrier through layer-by-layer selfassembly of chitosan and cellulose nanocrystals. Carbohydr. Polym. 92(2), 2128-2134 (2013)

59. A. Khan, R.A. Khan, S. Salmieri, C. Le Tien, B. Riedl, J. Bouchard, G. Chauve, V. Tan, M.R. Kamal, M. Lacroix, Mechanical and barrier properties of nanocrystalline cellulose reinforced chitosan based nanocomposite films. Carbohydr. Polym. 90(4), 1601-1608 (2012)

60. L.E. Nielsen, Models for the permeability of filled polymer systems. J. Macromol. Sci. Chem. 1(5), 929-942 (1967)

61. R.K. Bharadwaj, Modeling the barrier properties of polymerlayered silicate nanocomposites. Macromolecules 34(26), 9189$9192(2001)$

62. K. Yano, A. Usuki, A. Okada, T. Kurauchi, O. Kamigaito, Synthesis and Properties of Polyimide Clay Hybrid. J. Polym. Sci. A Polym. Chem. 31(10), 2493 (1993)

63. Z. Akbari, T. Ghomashchi, S. Moghadam, Improvement in Food Packaging Industry with Biobased Nanocomposites. Int. J. Food Eng. 3(4), 1-24 (2007)

64. M. Lavorgna, F. Piscitelli, P. Mangiacapra, G.G. Buonocore, Study of the combined effect of both clay and glycerol plasticizer on the properties of chitosan films. Carbohydr. Polym. 82(2), 291-298 (2010)

65. S.H. Park, H.S. Lee, J.H. Choi, C.M. Jeong, M.H. Sung, H.J. Park, Improvements in barrier properties of poly(lactic acid) films coated with chitosan or chitosan/clay nanocomposite. J. Appl. Polym. Sci. 125, E675-E680 (2012)

66. Q.Y. Wang, J.H. Guo, D.F. Xu, J. Cai, Y.T. Qiu, J.H. Ren, L.N. Zhang, Facile construction of cellulose/montmorillonite nanocomposite biobased plastics with flame retardant and gas barrier properties. Cellulose 22(6), 3799-3810 (2015)

67. K. Fatyeyeva, C. Chappey, S. Marais, Biopolymer/Clay Nanocomposites as the High Barrier Packaging Material: Recent Advances. Food Packag. 7, 425 (2017)

68. A. Nouri, M.T. Yaraki, M. Ghorbanpour, S. Agarwal, V.K. Gupta, Enhanced antibacterial effect of chitosan film using montmorillonite/cuo nanocomposite. Int. J. Biol. Macromol. 109, 1219-1231 (2018)

69. B. Moghadas, E. Dashtimoghadam, H. Mirzadeh, F. Seidi, M.M. Hasani-Sadrabadi, Novel chitosan-based nanobiohybrid membranes for wound dressing applications. RSC Adv. 6(10), 7701$7711(2016)$
70. M.P. Indumathi, K.S. Sarojini, G.R. Rajarajeswari, Antimicrobial and biodegradable chitosan/cellulose acetate phthalate/ $\mathrm{ZnO}$ nano composite films with optimal oxygen permeability and hydrophobicity for extending the shelf life of black grape fruits. Int. J. Biol. Macromol. 132, 1112-1120 (2019)

71. E. Lizundia, U. Goikuria, J.L. Vilas, F. Cristofaro, G. Bruni, E. Fortunati, I. Armentano, L. Visai, L. Torre, Metal nanoparticles embedded in cellulose nanocrystal based films: material properties and post-use analysis. Biomacromolecules 19(7), 2618-2628 (2018)

72. Z.H. Li, M. Zhang, D. Cheng, R.D. Yang, Preparation of silver nano-particles immobilized onto chitin nano-crystals and their application to cellulose paper for imparting antimicrobial activity. Carbohydr. Polym. 151, 834-840 (2016)

73. S. Amjadi, S. Emaminia, S.H. Davudian, S. Pourmohammad, H. Hamishehkar, L. Roufegarinejad, Preparation and characterization of gelatin-based nanocomposite containing chitosan nanofiber and ZnO nanoparticles. Carbohydr. Polym. 216, 376-384 (2019)

74. Y. Qin, Y.P. Liu, L.M. Yuan, H.M. Yong, J. Liu, Preparation and characterization of antioxidant, antimicrobial and $\mathrm{pH}$-sensitive films based on chitosan, silver nanoparticles and purple corn extract. Food Hydrocoll. 96, 102-111 (2019)

75. S. Hajji, R.B.S.B. Salem, M. Hamdi, K. Jellouli, W. Ayadi, M. Nasri, S. Boufi, Nanocomposite films based on chitosan-poly(vinyl alcohol) and silver nanoparticles with high antibacterial and antioxidant activities. Process. Saf. Environ. Prot. 111, 112-121 (2017)

76. M.S. Sarwar, M.B.K. Niazi, Z. Jahan, T. Ahmad, A. Hussain, Preparation and characterization of PVA/nanocellulose/Ag nanocomposite films for antimicrobial food packaging. Carbohydr. Polym. 184, 453-464 (2018)

77. P.M. Ma, L. Jiang, M.M. Yu, W.F. Dong, M.Q. Chen, Green antibacterial nanocomposites from poly(lactide)/poly(butylene adipate-co-terephthalate)/nanocrystal cellulose-silver nanohybrids. ACS Sustain. Chem. Eng. 4(12), 6417-6426 (2016)

78. J. Jung, G. Kasi, J. Seo, Development of functional antimicrobial papers using chitosan/starch-silver nanoparticles. Int. J. Biol. Macromol. 112, 530-536 (2018)

79. H.M.C. Azeredo, L.H.C. Mattoso, D. Wood, T.G. Williams, R.J. Avena-Bustillos, T.H. McHugh, Nanocomposite edible films from mango puree reinforced with cellulose nanofibers. J. Food Sci. 74(5), N31-N35 (2009)

80. D. Battegazzore, J. Alongi, A. Frache, Poly(lactic acid)-based composites containing natural fillers: thermal, mechanical and barrier properties. J. Polym. Environ. 22(1), 88-98 (2014)

81. C. Johansson, J. Bras, I. Mondragon, P. Nechita, D. Plackett, P. Simon, D.G. Svetec, S. Virtanen, M.G. Baschetti, C. Breen, F. Clegg, S. Aucejo, Renewable Fibers and Bio-Based Materials for Packaging Applications - a Review of Recent Developments. BioRes. 7(2), 2506 (2012)

82. V. Yousefi, D. Mohebbi-Kalhori, A. Samimi, Application of layer-by-layer assembled chitosan/montmorillonite nanocomposite as oxygen barrier film over the ceramic separator of the microbial fuel cell. Electrochim. Acta 283, 234-247 (2018)

83. H. Li, Y.Q. He, J. Yang, X. Wang, T.Q. Lan, L.C. Peng, Fabrication of food-safe superhydrophobic cellulose paper with improved moisture and air barrier properties. Carbohydr. Polym. 211, 22-30 (2019)

84. H. Zheng, J.P. Zhou, Y.M. Du, L.N. Zhang, Cellulose/chitin films blended in $\mathrm{NaOH} /$ urea aqueous solution. J. Appl. Polym. Sci. 86(7), 1679-1683 (2002)

85. S.M. Liang, L. Zhang, H. Xu, Morphology and permeability of cellulose/chitin blend membranes. J. Membr. Sci. 287(1), 19-28 (2007) 
86. S.A. Zhang, F.X. Li, J.Y. Yu, Preparation of Cellulose/Chitin Blend Bio-Fibers Via Direct Dissolution. Cellul. Chem. Technol. 43(9-10), 393 (2009)

87. E. Robles, A.M. Salaberria, R. Herrera, S.C.M. Fernandes, J. Labidi, Self-bonded composite films based on cellulose nanofibers and chitin nanocrystals as antifungal materials. Carbohydr. Polym. 144, 41-49 (2016)

88. H.D. Huang, C.Y. Liu, D. Li, Y.H. Chen, G.J. Zhong, Z.M. Li, Ultra-low gas permeability and efficient reinforcement of cellulose nanocomposite films by well-aligned graphene oxide nanosheets. J. Mater. Chem. A 2(38), 15853-15863 (2014)

89. S. Qin, M.G. Pour, S. Lazar, O. Koklukaya, J. Gerringer, Y.X. Song, L. Wagberg, J.C. Grunlan, Super Gas Barrier and Fire Resistance of Nanoplatelet/Nanofibril Multilayer Thin Films. Adv. Mater. Interfaces 6(2), 1801424 (2019)

90. L. Chen, C. Xiao, Y.L. Tang, X. Zhang, K. Zheng, X.Y. Tian, Preparation and properties of boron nitride nanosheets/cellulose nanofiber shear-oriented films with high thermal conductivity. Ceram. Int. 45(10), 12965-12974 (2019)

91. Y.B. Dou, S.M. Xu, X.X. Liu, J.B. Han, H. Yan, M. Wei, D.G. Evans, X. Duan, Transparent, flexible films based on layered double hydroxide/cellulose acetate with excellent oxygen barrier property. Adv. Funct. Mater. 24(4), 514-521 (2014)

92. J.W. Liu, H.W. Liang, S.H. Yu, Macroscopic-scale assembled nanowire thin films and their functionalities. Chem. Rev. 112(8), 4770-4799 (2012)

93. A. Javey, S. Nam, R.S. Friedman, H. Yan, C.M. Lieber, Layer-bylayer assembly of nanowires for three-dimensional, multifunctional electronics. Nano Lett. 7(3), 773-777 (2007)

94. Z.Y. Fan, J.C. Ho, Z.A. Jacobson, R. Yerushalmi, R.L. Alley, H. Razavi, A. Javey, Wafer-scale assembly of highly ordered semiconductor nanowire arrays by contact printing. Nano Lett. 8(1), 20-25 (2008)

95. A. Pevzner, Y. Engel, R. Elnathan, T. Ducobni, M. Ben-Ishai, K. Reddy, N. Shpaisman, A. Tsukernik, M. Oksman, F. Patolsky, Knocking down highly-ordered large-scale nanowire arrays. Nano Lett. 10(4), 1202-1208 (2010)

96. F. Xu, J.W. Durham, B.J. Wiley, Y. Zhu, Strain-release assembly of nanowires on stretchable substrates. ACS Nano 5(2), 1556$1563(2011)$

97. J. Cai, J.Y. Chen, Q. Zhang, M. Lei, J.R. He, A.H. Xiao, C.J. Ma, S. Li, H.G. Xiong, Well-aligned cellulose nanofiber-reinforced polyvinyl alcohol composite film: mechanical and optical properties. Carbohydr. Polym. 140, 238-245 (2016)

98. N. Song, D.L. Cao, X. Luo, Y.Q. Guo, J.W. Gu, P. Ding, Aligned cellulose/nanodiamond plastics with high thermal conductivity. J. Mater. Chem. C 6(48), 13108-13113 (2018)

99. J.G. Torres-Rendon, F.H. Schacher, S. Ifuku, A. Walther, Mechanical performance of macrofibers of cellulose and chitin nanofibrils aligned by wet-stretching: a critical comparison. Biomacromolecules 15(7), 2709-2717 (2014)

100. R. Chowdhury, Roll-to-roll fabrication of cellulose nanocrystal nanocomposite for gas barrier and thermal management applications. Doctoral dissertation, Purdue University Graduate School, 2019

101. A. Sangroniz, J.B. Zhu, X.Y. Tang, A. Etxeberria, E.Y.X. Chen, H. Sardon, Packaging materials with desired mechanical and barrier properties and full chemical recyclability. Nat. Commun. 10, 3559 (2019)

102. M. Karamanlioglu, R. Preziosi, G.D. Robson, Abiotic and biotic environmental degradation of the bioplastic polymer poly(lactic acid): a review. Polym. Degrad. Stab. 137, 122-130 (2017)

103. F.J. Arraez, M.L. Arnal, A.J. Muller, Thermal and UV degradation of polypropylene with pro-oxidant. Abiotic characterization. J. Appl. Polym. Sci. 135(14), 46088 (2018)
104. Y.K. Lukanina, N.N. Kolesnikova, A.A. Popov, A.V. Khvatov, Oxo-degradation of LDPE with pro-oxidant additive. IOP Conf. Ser. Mater. Sci. Eng. 525, 012104 (2019)

105. J.Z. Xu, W. Yang, C.Q. Zhang, X.M. Dong, Y. Luo, Photooxidation and biodegradation of polyethylene films containing polyethylene glycol modified $\mathrm{TiO} 2$ as pro-oxidant additives. Polym. Compos. 39, E531-E539 (2018)

106. J.Z. Xu, X. Wang, X.M. Yuan, J.J. Tao, S.J. Peng, W. Yang, X.M. Dong, C.Q. Zhang, Y. Luo, Polyaniline modified mesoporous titanium dioxide that enhances oxo-biodegradation of polyethylene films for agricultural plastic mulch application. Polym. Int. 68(7), 1332-1340 (2019)

107. S. Khajehpour-Tadavani, G.R. Nejabat, S.M.M. Mortazavi, Oxobiodegradability of high-density polyethylene films containing limited amount of isotactic polypropylene. J. Appl. Polym. Sci. 135(6), 45843 (2018)

108. Y.D.C. de Oliveira, L.G. Amurin, F.C.F. Valim, G.J.M. Fechine, R.J.E. Andrade, The role of physical structure and morphology on the photodegradation behaviour of polypropylene-graphene oxide nanocomposites. Polymer 176, 146-158 (2019)

109. T. Lu, E. Solis-Ramos, Y. Yi, M. Kumosa, UV degradation model for polymers and polymer matrix composites. Polym. Degrad. Stab. 154, 203-210 (2018)

110. J. Pospisil, P.P. Klemchuk, Oxidation Inhibition in Organic Materials (CRC Press, Boca Raton, 1989)

111. H. Roper, H. Koch, The role of starch in biodegradable thermoplastic materials. Starch-Starke 42(4), 123-130 (1990)

112. R. Narayan, in Soil Degradable Bioplastics for a Sustainable Modern Agriculture, ed. by M. Malinconico. Biodegradable and biobased plastics: an overview (Springer-Verlag GmbH, Berlin, 2017), p. 23

113. R.J. Müller, in Biopolymers Online, ed. by A. Steinbüchel. (Wiley-VCH, Weinheim, 2005)

114. T. Ahmed, M. Shahid, F. Azeem, I. Rasul, A. Shah, M. Noman, A. Hameed, N. Manzoor, I. Manzoor, S. Muhammad, Biodegradation of plastics: current scenario and future prospects for environmental safety. Environ. Sci. Pollut. Res. 25(8), 7287 7298 (2018)

115. J. Bras, M.L. Hassan, C. Bruzesse, E.A. Hassan, N.A. El-Wakil, A. Dufresne, Mechanical, barrier, and biodegradability properties of bagasse cellulose whiskers reinforced natural rubber nanocomposites. Ind. Crop. Prod. 32(3), 627-633 (2010)

116. M. Hasan, T.K. Lai, D.A. Gopakumar, M. Jawaid, F.A.T. Owolabi, E.M. Mistar, T. Alfatah, N.Z. Noriman, M.K.M. Haafiz, H.P.S.A. Khalil, Micro crystalline bamboo cellulose based seaweed biodegradable composite films for sustainable packaging material. J. Polym. Environ. 27(7), 1602-1612 (2019)

117. N. Suderman, M.I.N. Isa, N.M. Sarbon, Effect of drying temperature on the functional properties of biodegradable CMC-based film for potential food packaging. Int. Food Res. J. 23(3), 1075 (2016)

118. N.A. Mostafa, A.A. Farag, H.M. Abo-dief, A.M. Tayeb, Production of biodegradable plastic from agricultural wastes. Arab. J. Chem. 11(4), 546-553 (2018)

119. S. Ramesh, P. Radhakrishnan, Cellulose nanoparticles from agroindustrial waste for the development of active packaging. Appl. Surf. Sci. 484, 1274-1281 (2019)

120. S. Bandyopadhyay, N. Saha, U.V. Brodnjak, P. Saha, Bacterial cellulose and guar gum based modified PVP-CMC hydrogel films: Characterized for packaging fresh berries Food Packag. Shelf Life 22, 100402 (2019)

121. L. Hai, E.S. Choi, L. Zhai, P.S. Panicker, J. Kim, Green nanocomposite made with chitin and bamboo nanofibers and its mechani$\mathrm{cal}$, thermal and biodegradable properties for food packaging. Int. J. Biol. Macromol. 144, 491-499 (2020)

122. J. Zhang, W.R. Xu, Y.C. Zhang, X.D. Han, C. Chen, A. Chen, In situ generated silica reinforced polyvinyl alcohol/liquefied chitin 
biodegradable films for food packaging. Carbohydr. Polym. 238, $116182(2020)$

123. M. Hasan, D.A. Gopakumar, N.G. Olaiya, F. Zarlaida, A. Alfian, C. Aprinasari, T. Alfatah, S. Rizal, H.P.S.A. Khalil, Evaluation of the thermomechanical properties and biodegradation of brown rice starch-based chitosan biodegradable composite films. Int. J. Biol. Macromol. 156, 896-905 (2020)

124. A. Riaz, C. Lagnika, H. Luo, Z.Q. Dai, M.M. Nie, M.M. Hashim, C.Q. Liu, J.F. Song, D.J. Li, Chitosan-based biodegradable active food packaging film containing Chinese chive (Allium tuberosum) root extract for food application. Int. J. Biol. Macromol. 150, 595-604 (2020)

125. Z. Yu, B.Q. Li, J.Y. Chu, P.F. Zhang, Silica in situ enhanced PVA chitosan biodegradable films for food packages. Carbohydr. Polym. 184, 214-220 (2018)

126. S.E.A. Mohd Asri, Z. Zakaria, A. Hassan, M.H. Mohamad Kassim, Effect of chitin source and content on properties of chitin nanowhiskers filled polylactic acid composites. IIUM Eng. J. 21(2), 239-255 (2020)

127. J.M.F. Pavoni, C.L. Luchese, I.C. Tessaro, Impact of acid type for chitosan dissolution on the characteristics and biodegradability of cornstarch/chitosan based films. Int. J. Biol. Macromol. 138, 693703 (2019)

128. I. Mutmainna, D. Tahir, P.L. Gareso, S. Ilyas, A. Saludung, Improving Degradation Ability of Composite Starch/Chitosan by Additional Pineapple Leaf Microfibers for Food Packaging Applications. IOP Conf. Ser. Mater. Sci. Eng. 593, 012024 (2019)

129. R. Suriyatem, R.A. Auras, P. Rachtanapun, Improvement of mechanical properties and thermal stability of biodegradable rice starch-based films blended with carboxymethyl chitosan. Ind. Crop. Prod. 122, 37-48 (2018)

130. R. Suriyatem, R.A. Auras, C. Rachtanapun, P. Rachtanapun, Biodegradable Rice Starch/Carboxymethyl Chitosan Films with Added Propolis Extract for Potential Use as Active Food Packaging. Polymers 10(9), 954 (2018)

131. J.M.F. Pavoni, N.Z. dos Santos, I.C. May, L.D. Pollo, I.C. Tessaro, Impact of acid type and glutaraldehyde crosslinking in the physicochemical and mechanical properties and biodegradability of chitosan films. Polym. Bull. (2020), https://doi.org/10. 1007/s00289-020-03140-4

132. I. Hamed, F. Ozogul, J.M. Regenstein, Industrial applications of crustacean by-products (chitin, chitosan, and chitooligosaccharides): A review. Trends Food Sci. Technol. 48, 40-50 (2016)

133. S.K. Shukla, A.K. Mishra, O.A. Arotiba, B.B. Mamba, Chitosanbased nanomaterials: A state-of-the-art review. Int. J. Biol. Macromol. 59, 46-58 (2013)

134. P. Bajpai, Recycling and deinking of recovered paper (Elsevier, Amsterdam, 2013), pp. 2-7

135. Facts and figures about materials, waste and recycling. (USEPA, 2018). https://www.epa.gov/facts-and-figures-about-materialswaste-and-recycling/national-overview-facts-and-figuresmaterials Accessed 31 Aug 2020

136. C. Oliva, W. Huang, S. El Badri, M.A.L. Lee, J. Ronholm, L. Chen, Y. Wang, Concentrated sulfuric acid aqueous solution enables rapid recycling of cellulose from waste paper into antimicrobial packaging. Carbohydr. Polym. 241, 116256 (2020)

137. G. Martínez-Barrera, M. Martínez-López, N. González-Rivas, J.J. del Coz-Diaz, L. Ávila-Córdoba, J.M.L. dos Reis, O. Gencel, Recycled cellulose from Tetra Pak packaging as reinforcement of polyester based composites. Constr. Build. Mater. 157, 1018-1023 (2017)

138. V. Brummer, T. Jurena, V. Hlavacek, J. Omelkova, L. Bebar, P. Gabriel, P. Stehlik, Enzymatic hydrolysis of pretreated waste paper - source of raw material for production of liquid biofuels. Bioresour. Technol. 152, 543-547 (2014)
139. Y.H. Dun, Y.Q. Li, J.H. Xu, Y.L. Hu, C.Y. Zhang, Y.X. Liang, S.M. Zhao, Simultaneous fermentation and hydrolysis to extract chitin from crayfish shell waste. Int. J. Biol. Macromol. 123, 420 $426(2019)$

140. C.T. Doan, T.N. Tran, V.B. Nguyen, T.P.K. Vo, A.D. Nguyen, S.L. Wang, Chitin extraction from shrimp waste by liquid fermentation using an alkaline protease-producing strain, Brevibacillus parabrevis. Int. J. Biol. Macromol. 131, 706-715 (2019)

141. L.D. Tolesa, B.S. Gupta, M.J. Lee, Chitin and chitosan production from shrimp shells using ammonium-based ionic liquids. Int. J. Biol. Macromol. 130, 818-826 (2019)

142. H. Abushammala, I. Krossing, M.P. Laborie, Ionic liquidmediated technology to produce cellulose nanocrystals directly from wood. Carbohydr. Polym. 134, 609-616 (2015)

143. P. Phanthong, S. Karnjanakom, P. Reubroycharoen, X.G. Hao, A. Abudula, G.Q. Guan, A facile one-step way for extraction of nanocellulose with high yield by ball milling with ionic liquid. Cellulose 24(5), 2083-2093 (2017)

144. H.Y. Yang, G. Gozaydin, R.R. Nasaruddin, J.R.G. Har, X. Chen, X.N. Wang, N. Yan, Toward the shell biorefinery: processing crustacean shell waste using hot water and carbonic acid. ACS Sustain. Chem. Eng. 7(5), 5532-5542 (2019)

145. F. Ansari, M. Salajkova, Q. Zhou, L.A. Berglund, Strong surface treatment effects on reinforcement efficiency in biocomposites based on cellulose nanocrystals in poly(vinyl acetate) matrix. Biomacromolecules 16(12), 3916-3924 (2015)

146. J.H. Wang, L. Wang, H.J. Yu, Zain-ul-Abdin, Y.S. Chen, Q. Chen, W.D. Zhou, H.T. Zhang, X. Chen, Recent progress on synthesis, property and application of modified chitosan: An overview. Int. J. Biol. Macromol. 88, 333 (2016)

147. F. Ferreira, I. Pinheiro, R. Gouveia, G. Thim, L. Lona, Functionalized cellulose nanocrystals as reinforcement in biodegradable polymer nanocomposites. Polym. Compos. 39, E9-E29 (2018)

148. T. Saito, S. Kimura, Y. Nishiyama, A. Isogai, Cellulose nanofibers prepared by TEMPO-mediated oxidation of native cellulose. Biomacromolecules 8(8), 2485-2491 (2007)

149. L. Wagberg, G. Decher, M. Norgren, T. Lindstrom, M. Ankerfors, K. Axnas, The build-up of polyelectrolyte multilayers of microfibrillated cellulose and cationic polyelectrolytes. Langmuir 24(3), 784-795 (2008)

150. F.C. Nan, S. Nagarajan, Y.W. Chen, P. Liu, Y.X. Duan, Y.F. Menm, J.M. Zhang, Enhanced toughness and thermal stability of cellulose nanocrystal iridescent films by alkali treatment. ACS Sustain. Chem. Eng. 5(10), 8951-8958 (2017)

151. H. Lee, J. Sundaram, L. Zhu, Y.P. Zhao, S. Mani, Improved thermal stability of cellulose nanofibrils using low-concentration alkaline pretreatment. Carbohydr. Polym. 181, 506-513 (2018)

152. K. Littunen, U. Hippi, L.S. Johansson, M. Osterberg, T. Tammelin, J. Laine, J. Seppala, Free radical graft copolymerization of nanofibrillated cellulose with acrylic monomers. Carbohydr. Polym. 84(3), 1039-1047 (2011)

153. N. Lavoine, J. Bras, T. Saito, A. Isogai, Improvement of the thermal stability of TEMPO-oxidized cellulose nanofibrils by heatinduced conversion of ionic bonds to amide bonds. Macromol. Rapid Commun. 37(13), 1033-1039 (2016)

154. N. Zhang, P. Tao, Y.X. Lu, S.X. Nie, Effect of lignin on the thermal stability of cellulose nanofibrils produced from bagasse pulp. Cellulose 26(13-14), 7823-7835 (2019)

155. C. Tang, S. Zhang, X.B. Wang, J. Hao, Enhanced mechanical properties and thermal stability of cellulose insulation paper achieved by doping with melamine-grafted nano-SiO2. Cellulose 25(6), 3619-3633 (2018)

156. G.F. de Lima, A.G. de Souza, C.R. Bauli, R.F.D. Barbosa, D.B. Rocha, D.D. Rosa, Surface modification effects on the thermal stability of cellulose nanostructures obtained from lignocellulosic residues. J. Therm. Anal. Calorim. 141(4), 1263-1277 (2020) 